\title{
On the food of northern krill Meganyctiphanes norvegica in relation to its vertical distribution
}

\author{
Sandra Lass ${ }^{1, * *}$, Geraint A. Tarling ${ }^{2, *}$, Patti Virtue ${ }^{3,4}$, Jack B. L. Matthews ${ }^{2}$, \\ Patrick Mayzaud ${ }^{3}$, Friedrich Buchholz ${ }^{1}$ \\ ${ }^{1}$ Alfred-Wegener-Institut für Polar- und Meeresforschung, c/o Biologische Anstalt Helgoland, Meeresstation, Postfach 180, \\ 27483 Helgoland, Germany \\ ${ }^{2}$ Scottish Association for Marine Science, PO Box 3, Oban, Argyll PA34 5DH, United Kingdom \\ ${ }^{3}$ Laboratoire d'Océanographie Biochimique et d'Ecologie, Observatoire Océanologique BP 28, \\ 06230 Villefranche-sur-Mer, France \\ ${ }^{4}$ IASOS, University of Tasmania, GPO Box 252-77, Hobart, Tasmania, Australia
}

\begin{abstract}
The feeding behaviour of northern krill (Meganyctiphanes norvegica) was studied in populations from the Clyde Sea and the Kattegat during summer and winter. The food spectrum in the stomachs was analysed using traditional taxonomic methods and biochemical techniques. The vertical migration behaviour of krill was monitored through a $30 \mathrm{~h}$ series of net samples, whilst the trophic environment was characterised through accompanying quantitative analyses on the depth distribution and biomass of copepods and phytoplankton. Krill was found to be more carnivorous in the Kattegat than in the Clyde Sea, which correlated with the higher ratio of copepod to phytoplankton biomass found in the Kattegat compared with the Clyde Sea. High levels of fatty alcohols and other lipid markers in the stomach contents of Kattegat krill were also indicative of a carnivorous diet. Other food sources included detritus, terrestrial material and other euphausiids, underlining the opportunistic nature of northern krill in its choice of prey items. Analyses of stomach and intestinal fullness over a diel cycle showed significant variations with time in the Clyde Sea but not in the Kattegat. However, a diel cycle in the rate of ingestion was evident at both locations when comparing the copepod mandibles in the stomachs to the distribution of copepods in the environment. The fact that deep-living Calanus was not a major prey item suggested that there was little feeding activity during the daytime, when the krill occupied the deeper layers. Instead, the majority of mandibles were from species that were dominant in the upper layers, e.g. the genera Temora and Pseudocalanus. The fact that krill caught in the daytime contained the same relative composition of mandibles in the stomach as those caught at night is probably explained by a cessation in daytime feeding activity and retention of the mandibles from the night before. It is proposed that krill in the Clyde Sea area and the Kattegat show a diel rhythm in feeding activity that is believed to be an adaptive response to minimising predation risk.
\end{abstract}

KEY WORDS: Krill $\cdot$ Meganyctiphanes norvegica $\cdot$ Diet $\cdot$ Vertical migration $\cdot$ Fatty acids $\cdot$ Alcohols $\cdot$ Sterols

Resale or republication not permitted without written consent of the publisher

\section{INTRODUCTION}

Northern krill, Meganyctiphanes norvegica (Crustacea: Euphausiacea), has a very wide distribution throughout the North Atlantic, in the region of the con-

\footnotetext{
*Corresponding author. E-mail: gant@dml.ac.uk

${ }^{* *}$ Present address: EAWAG/ETH, Department of Limnology, Ueberlandstrasse 133, 8600 Duebendorf, Switzerland
}

tinental slope and in deep basins near the coast (Einarsson 1945). As a species, therefore, it is capable of adapting successfully to a wide range of climatic conditions. How it does this from place to place can provide indications of how this particular member of the zooplankton community could adapt to changing conditions through time in a given region. Moreover, the extraordinary success of $M$. norvegica in so many places makes it a major consumer of phytoplankton 
and of smaller zooplankton on the one hand as well as a major prey of many species of fish and whales, on the other hand. Any attempt to manage sustainably the stocks of fish that are dependent on this species must therefore take due account of its trophic position. Accordingly, $M$. norvegica has been the subject of an interdisciplinary project under the EU MAST III Programme, the PEP Project (see 'Acknowledgements'). Within this project, the aims of the present study were to elucidate aspects of the diet of $M$. norvegica, particularly the carnivorous component, in relation to vertical migration and food availablity.

Meganyctiphanes norvegica is best described as an opportunistic omnivore, with a diet that varies with season and location. Mauchline \& Fisher (1969) showed that $M$. norvegica feeds more intensively during the summer than in winter and that variations in diet are related to seasonal variations in the occurrence of planktonic crustaceans and phytoplankton, especially dinoflagellates. In northern Norway, the copepod Calanus finmarchicus made up between 85 and $95 \%$ of the biomass of copepod prey taken by $M$. norvegica, but carnivory was less important in specimens from the Skagerrak (Båmstedt \& Karlson 1998). In Oslofjorden (southern Norway), krill fed heavily on phytoplankton at night and on copepods during both day and night (Onsrud \& Kaartvedt 1998), a pattern similar to that found in the Bay of Fundy, Canada (Sameoto 1980), and in Loch Fyne on the west coast of Scotland (Mauchline 1960).

Northern krill characteristically performs a pronounced diel vertical migration throughout its distributional range (Mauchline 1960, Sameoto 1980, Nicol 1984, Simmard et al. 1986, Buchholz et al. 1995, Bergström \& Strömberg 1997, Onsrud \& Kaartvedt 1998, Tarling et al. 1998, 1999). This behaviour is widely believed to reflect the trade-off between gaining an adequate energy intake from the food-rich surface layers, whilst minimising predation risk through avoiding habitats with high light levels (Gabriel \& Thomas 1988, Mangel \& Clark 1988, Tarling et al. 2000). Increases in gut contents during nighttime are believed to be a response to migration into food-rich layers rather than an increase in feeding activity relative to the daytime. Little consideration has been given to this latter hypothesis because several studies have found copepod remains in guts during daytime (e.g. Mauchline 1960, Onsrud \& Kaartvedt 1998), which has been taken to indicate that krill feed during daytime as well as at night. However, as discussed by Murtaugh (1984), any attempt to interpret the presence or absence of circadian rhythms in feeding rate from gut fullness alone is problematic, since gut residence times vary with temperature and the rate of food intake. In order to determine the time and place of feeding, it is necessary to obtain information on (1) the species composition of gut contents, (2) the vertical distribution of prey items in the environment, and (3) the vertical migration of the feeding animal.

In the present study we obtained information on each of these 3 aspects to gain a comprehensive picture of the feeding behaviour of Meganyctiphanes norvegica. Stomach and intestinal contents of $M$. norvegica were examined using a combination of traditional taxonomic methods and biochemical markers (signature lipids) in order to identify major prey items and to assess the extent of herbivory and carnivory. The vertical migration of $M$. norvegica was studied through a series of depth-discrete net hauls carried out over a $30 \mathrm{~h}$ period, whilst the food environment was described from plankton samples and chlorophyll $a$ profiles. The study was carried out in 2 different areas, the Clyde Sea and the Kattegat, differing considerably in both their hydrography and their food environments, such that site-specific characters could be distinguished from general features such as circadian rhythms. Sampling was carried out in summer and winter in order to take account of seasonal changes in day-length, food availability and temperature.

\section{MATERIALS AND METHODS}

Krill sampling. Net sampling was carried out in July 1996 and in February/March 1997 in the Arran Deep in the Clyde Sea area $\left(55^{\circ} 40^{\prime} \mathrm{N}, 5^{\circ} 05^{\prime} \mathrm{W}\right)$ and in the Alkor Deep in the Kattegat $\left(57^{\circ} 17^{\prime} \mathrm{N}, 11^{\circ} 25^{\prime} \mathrm{E}\right)$. The Arran Deep is the northern part of a trench some $0.5 \mathrm{~km}$ wide and $150 \mathrm{~m}$ deep; it runs north to south, parallel to the east coast of Arran, and connects with the main part of the Clyde Sea, which is separated from the open water of the Irish Sea and North Channel by the Great Plateau at $<50 \mathrm{~m}$ depth. The trench continues north into Loch Fyne and west into Kilbrannon Sound, over a series of sills that become progressively more shallow. The Alkor Deep is a trench some $3.5 \mathrm{~km}$ long and $1 \mathrm{~km}$ wide; it has a maximum depth of $134 \mathrm{~m}$ and links with the Kattegat to the north, over a series of sills, the shallowest at $50 \mathrm{~m}$ depth, in an area where the average water depth is $23 \mathrm{~m}$. Tidal and wind-driven currents are quite strong in the Arran Deep, often with a counter current apparent in deeper layers. Despite this, stratification is persistent between May and October; this breaks down in November after which bottom water is renewed intermittently with water of Atlantic and Irish Sea origin until stratification is re-established the following April. The Kattegat is characterised by northward-flowing, low-salinity water in the upper layers and more saline water that originates from the North Sea that fills the deeps. Tem- 
peratures fluctuate widely near the surface between winter and summer, but are relatively constant in the deep water, affected mainly by flushing events. A full description of the sites and the sampling programmes is given by Matthews et al. (1999).

A series of 11 multi-net deployments was made on 4 to 5 July 1996 and 21 to 22 February 1997 in the Arran Deep and on 18 to 19 July 1996 and 16 to 17 March 1997 in the Alkor Deep in order to obtain krill for examination of stomach and gut contents. The multinet device was a $1 \mathrm{~m}^{2}$ MOCNESS (Wiebe et al. 1985) equipped with 9 nets, a flowmeter, and temperature, salinity and depth sensors. Net 1, with a $330 \mu \mathrm{m}$ mesh, was open during the descent of the net to within $15 \mathrm{~m}$ of bottom (150 m in the Arran Deep; $130 \mathrm{~m}$ in the Alkor Deep). The other nets, with a $2 \mathrm{~mm}$ mesh, were opened sequentially while the net was being hauled in, so that the water column was sampled in discrete depth intervals of $\leq 20 \mathrm{~m}$. The net was lowered at $0.5 \mathrm{~m} \mathrm{~s}^{-1}$ and raised at $0.2 \mathrm{~m} \mathrm{~s}^{-1}$; the towing speed was 2.5 knots. The sampling series were carried out for a minimum of $24 \mathrm{~h}$, during which deployments were made at least every $6 \mathrm{~h}$ so that samples were obtained during the cardinal points of the day (i.e. midnight, dawn, midday and dusk). Samples were immediately frozen at $-30^{\circ} \mathrm{C}$ for further analysis in the home laboratory. Samples used for lipid analysis were transferred to $-80^{\circ} \mathrm{C}$ conditions, at which they were maintained until analysed.

Trophic environment. Additional net samples using a $1 \mathrm{~m}^{2}$ MOCNESS equipped with nine $330 \mu \mathrm{m}$ mesh nets were taken close to the above sampling periods for the collection of smaller zooplankton that might be fed upon by krill catching their food in 'predatory mode' as opposed to by filtration ('grazing mode') (Matthews et al. 2000). These deployments were made around midnight and midday and sampled the water column in the same depth intervals as in the case of the krill catches. Samples were frozen on board $\left(-30^{\circ} \mathrm{C}\right)$ and later thawed in the home laboratory, where species were identified and counted and biomass determined.

Morphometric analysis. Krill carapaces were measured from the tip of the rostrum to the postero-lateral border of the carapace (Scotex I, $\mathrm{n}=3098$; Scotex II, $\mathrm{n}=$ 2464; Kattex I, n = 1054; Kattex II, $\mathrm{n}=3000$ ); this was considered the most reliable estimate of body size given the damage that could occur to other body parts, such as the telson. Total length (front of the eye to tip of telson) and carapace length were measured on undamaged specimens from each cruise $(n=1960)$ in order to derive a common calibration curve. Lengthfrequency plots were made from the data, and year classes were distinguished by the 'Petersen' method (see Gibbons et al. 1999). The standard deviation was calculated by dividing the difference between the val- ues at $50 \%$ and at $99.999 \%$ of the year class by 3.72 (see Omori \& Ikeda 1984).

Feeding state. Subsamples of 20 adults from each sample were randomly selected, and the gut contents examined under a stereo-microscope. This led to a total of 896 analysed stomachs (from the Clyde Sea: 306 in summer and 215 in winter, from the Kattegat: 176 in summer and 199 in winter). Intestine fullness was estimated in a semi-quantitative fashion by counting the number of thoracic and abdominal segments containing faecal strings (Klages 1979, Morris \& Ricketts 1984) and expressed on a 9-point scale from 0 to $100 \%$. The stomach was dissected out, and its fullness was estimated on a 5-point scale from 0 to $100 \%$ (Ponomareva 1971).

Stomach analysis. The contents of the 896 analysed stomachs were fixed and stained with a solution of polyvinyl-lactophenol and Orange $\mathrm{G}$ and then examined under a microscope where the main food items were identified and their abundance estimated semiquantitatively. Copepod mandibles were identified to species (Sars 1903, Anraku \& Omori 1963, Itoh 1970, Schnack 1982, Karlson \& Båmstedt 1994), counted and used to calculate various statistics. To examine fullness quantitatively, the average number of mandibles of the 3 most abundant copepods in all stomachs was calculated for each sample. Mandibles of other copepod species were not taken into account because they were rare in the stomachs and therefore of minor importance to the analysis of quantative fullness. For qualitative comparisons, the total number of mandibles in the stomach was divided into the number of mandibles from each species such that the percentage composition of each mandible type in the stomach was obtained. These values were compared against the relative abundance of copepod species in the trophic environment, also expressed as percentages.

Lipid extraction and analysis. Stomachs were dissected and the lipids extracted quantitatively using the modified Bligh \& Dyer (1959) technique (see Virtue et al. 1996). The contents of 30 stomachs were pooled for each sample, and 1 sample was analysed from each cruise. The majority of stomachs used for analysis were full, and those less than half full were discarded. Adult krill of similar size were selected from nighttime catches taken at the surface, close to the stations where samples were taken for microscopy. Total lipid was determined gravimetrically. Sterols and other neutral compounds were obtained by saponification of a portion of the total lipid. Another portion of the total lipid was methylated to produce fatty-acid methyl esters (Virtue et al. 1996). Gas chromatographic (GC) analyses were performed with a Perkin Elmer XL gas chromatograph, equipped with a J and W fused-silica capillary column (SE-30), an FID and a split injector 
system. Helium was used as the carrier gas. Samples were dissolved in chloroform to which a known amount of methylnonadecanoate was added as an internal standard. Individual components were identified by comparing retention times with those obtained for authentic and laboratory standards, using GC-MS data (see below). GC results were subject to an error of $\pm 5 \%$ of individual fatty acids. Gas chromatographicmass spectrometric (GC-MS) analyses of selected samples were performed on a Fisons MD 800 spectrometer (Manchester, UK), fitted with an on-column injector. The spectrometer was operated in scan mode with an ionising voltage of $70 \mathrm{eV}$.

Statistics. Parametric and non-parametric analyses: Differences in the intestine and stomach fullness with respect to time of day and sampling depth were tested using a 1-way ANOVA on ranks (Kruskal-Wallis). Where significant differences were found, a pair-wise multiple comparison procedure (Dunn's method) was used to isolate those groups that showed the greatest differences. In the case of the Kattegat summer samples, a rank sum test (Mann-Whitney) was used instead, because animals were only caught at 2 different depths.

Multivariate analyses: Hierarchical classification (PRIMER Version 4.0; Clarke \& Warwick, Plymouth Marine Laboratory, UK) was used to compare the relative abundances of different copepod species in the trophic environment to those in the stomachs. Two data sets were analysed, one containing all relative abundance data (as percentages) from the Clyde Sea (i.e. stomach and trophic environment in both summer and winter) and the other, all relative abundance data from the Kattegat. The data sets were clustered using a Bray-Curtis similarity coefficient and average linkage. Groups were separated at a number of similarity levels in order to reveal both the similarities and differences between stomach and trophic environment groups as fully as possible.

\section{RESULTS}

\section{Hydrography}

The hydrographic data collected during each of the cruises have been presented by Matthews et al. (1999) so only a brief overview of pertinent hydrographic features is given here. The Clyde Sea exhibits stratification in the summer, when temperatures were up to $2^{\circ} \mathrm{C}$ warmer in the surface water $\left(11^{\circ} \mathrm{C}\right)$ than near the bottom $\left(9^{\circ} \mathrm{C}\right)$. The halocline was less pronounced than the thermocline, although the warmer surface water was less saline (32.5 PSU) than the deeper water (34.2 PSU). In the winter, the temperature and salinity range through the water column was relatively narrow
(7.0 to $7.4^{\circ} \mathrm{C}$ and 33.2 to 33.8 PSU respectively), with transient, low-salinity water appearing at the surface.

In the Alkor Deep, Kattegat, temperature and salinity profiles exhibited a 3-layered stratification in summer, consisting of rather changeable surface and intermediate layers and a nearly isothermal deep layer. Surface temperatures ranged from $14^{\circ} \mathrm{C}$ to $17^{\circ} \mathrm{C}$, whilst those in the intermediate layers ranged from $7^{\circ} \mathrm{C}$ to $14^{\circ} \mathrm{C}$; the deep layer was around $6^{\circ} \mathrm{C}$. The salinity gradient was smoother than that of temperature, increasing from between 27.0 and 30.0 PSU at the surface to 34.0 PSU in the deepest layers. During the winter, the 3-layered salinity stratification was still apparent, although values in the deeper water (33.5 PSU) were a little lower than in the summer. The temperature was the same throughout the water column, around $4^{\circ} \mathrm{C}$, indicating that some mixing had taken place.

\section{Biotic environment}

Matthews et al. (2000) have reported potential prey items in plankton samples taken by day and night in conjunction with population sampling of Meganyctiphanes norvegica. There were considerable differences in abundance of the various species and to some extent in the overall species composition. Although gelatinous organisms (Aurelia aurita, Cyanea capillata, Beroe spp., Pleurobrachia pileus) often added much bulk to the sample, their large individual size made them unsuitable prey items (they were more likely to be predators on krill), and, in all cases, copepods comprised the main element among the firmbodied plankters.

As a measure of the available carnivorous food, total copepod biomass was calculated in relation to depth by day and night on both cruises in the Clyde Sea and Kattegat (Fig. 1a,b). During the summer in the Clyde Sea, the bulk of copepod biomass was above $60 \mathrm{~m}$ both night and day, although the maximum value was higher in the water column at night $\left(33 \mathrm{mg} \mathrm{DW} \mathrm{m}^{-3}\right.$ at 25 to $10 \mathrm{~m}$ compared with $8 \mathrm{mg} \mathrm{DW} \mathrm{m}^{-3}$ at 40 to $20 \mathrm{~m}$ ). The copepod biomass was considerably less during the winter, reaching a maximum of only $0.22 \mathrm{mg} \mathrm{DW} \mathrm{m}^{-3}$. As in the summer, the largest biomass in winter was found between 20 and $10 \mathrm{~m}$ at night and even deeper during the day.

Copepod biomass was greater in the Kattegat than in the Clyde Sea. Depth-integrated values in summer were between 72 and $77 \mathrm{mg} \mathrm{DW} \mathrm{m}^{-2}$ in the Kattegat compared with 21 to $54 \mathrm{mg} \mathrm{DW} \mathrm{m}^{-2}$ in the Clyde Sea, whilst winter values were between 41 and $72 \mathrm{mg}$ DW

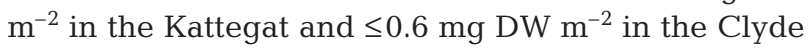
Sea. The distribution of biomass was broader in the Kattegat than in the Clyde Sea (values between 5 and 

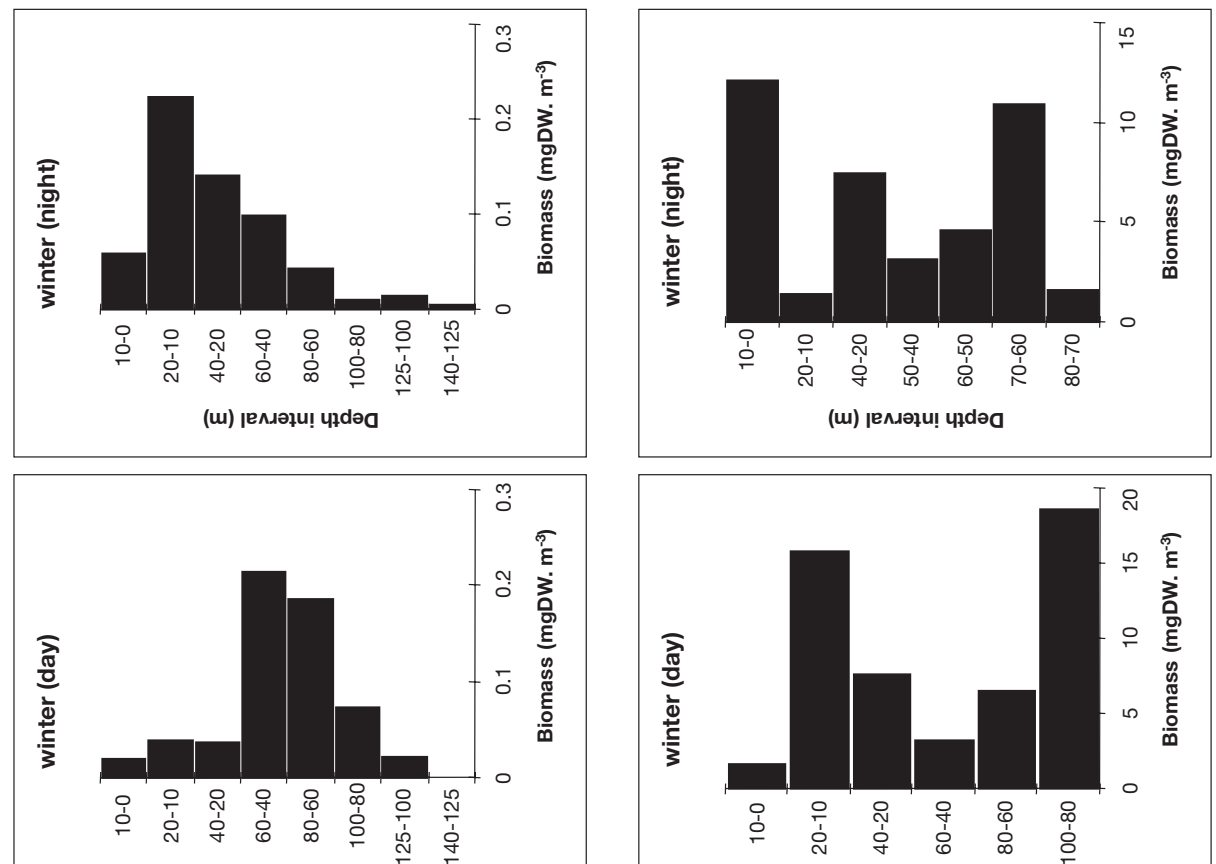

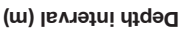

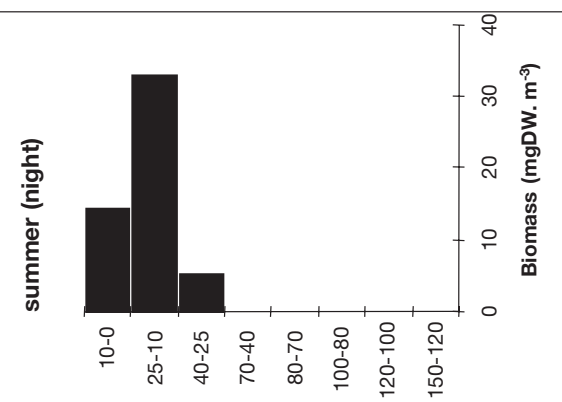

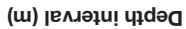
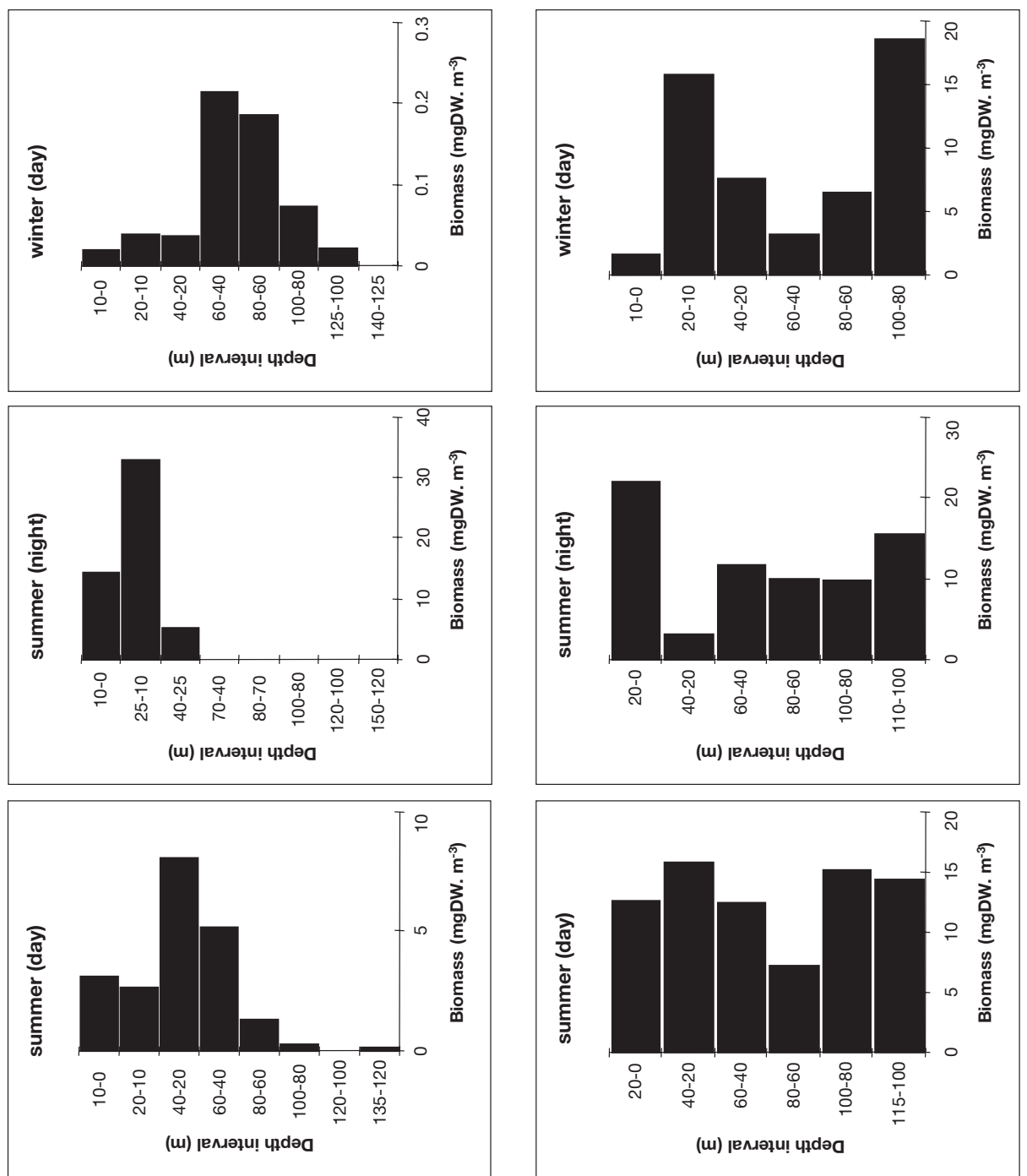

ఠ

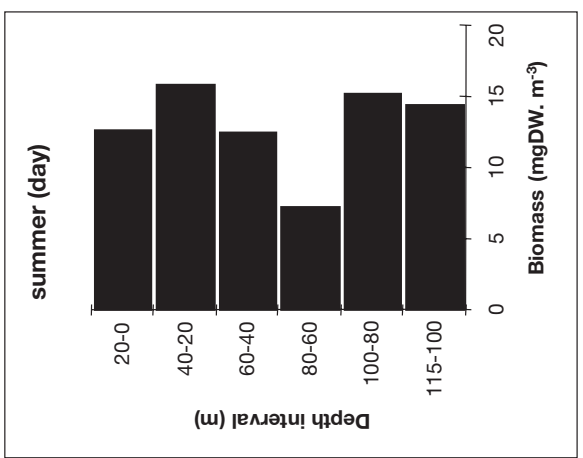

으 
$15 \mathrm{mg} \mathrm{DW} \mathrm{m}{ }^{-3}$ were found at most depths in both seasons day and night). The only clear pattern was the increase in biomass above $20 \mathrm{~m}$ at night in summer and winter, greater there than at any other depth $(22 \mathrm{mg}$ DW m ${ }^{-3}$ summer; $12 \mathrm{mg} \mathrm{DW} \mathrm{m}^{-3}$ winter).

The vertical distribution of the 11 types of copepods found most commonly in both environments is presented in Fig. 2 for the Clyde Sea and in Fig. 3 for the Kattegat. The figures include data from day and night hauls in both the summer (CI and KI for Clyde and Kattegat respectively) and the winter (CII and KII ) sampling campaigns.

Although the epiplanktonic species (Centropages hamatus, Temora longicornis and Acartia clausi) were much less common in winter than in summer, they tended in both seasons to be rather more dispersed in the upper layers in the Clyde Sea by day and to concentrate very near the surface at night. The same tendency, but over a wider depth range, was seen in the case of Calanus Stages V to VI and III to IV and Para-/ Pseudocalanus. The boundary between the surface and subsurface communities in the Clyde Sea is quite well marked at $40 \mathrm{~m}$ depth during the day and at $20 \mathrm{~m}$ at night. In the case of the Kattegat there were also signs of diurnal vertical migration, but they were much less consistent, and there was little evidence of a change in the community at any particular position in the water column; in fact Temora longicornis remained quite common in the winter and was dispersed throughout the water column, indicating perhaps a different overwintering strategy involving diapause rather than resting stages.

\section{Morphometric data}

Table 1 presents the mean total length $(\mathrm{mm})$ and standard deviation of the year classes of Meganyctiphanes norvegica present during the time of sampling, plus the mean total length and standard deviation of the animals considered in the gut-content analysis. During the summer cruise in the Clyde Sea, the krill used for gut-content analysis were principally Year 1 and Year 2 animals, whilst during the winter cruise, selected animals were principally from the Year 2 cohort. In the Kattegat, animals selected for gut-content analysis were from either the Year 1 or Year 2 cohorts in the summer, whilst in the winter the larger animals from the Year 2 cohort were selected.

\section{Vertical distribution}

Fig. $4 a-d$ present the vertical distribution of krill throughout the day/night cycle, expressed as the per- centage of individuals in each depth interval relative to the total number of individuals in the water column at that time. Percentage distributions illustrate the vertical migration pattern better than absolute concentrations because of the variation in the total amount of krill in net-catches between different times of day and between days. Fig. 4 may be converted to absolute concentrations using the depth-integrated concentration values given in Table 2. Both Fig. 4 and Table 2 are constructed from data spanning several days to give the most representative picture possible. Values in Table 2 are given as a range to illustrate the degree of variation in net-catch concentrations of krill between deployments. The times at which deployments were made to obtain krill for gut and stomach analysis are indicated.

During the summer cruise in the Clyde Sea, most of the population (52\%) occurred between 80 and $100 \mathrm{~m}$ during daytime (14:00 h). By 20:00 h, most individuals had migrated upwards to between 80 and $40 \mathrm{~m}$ and this continued until, by $23: 00 \mathrm{~h}, 49 \%$ of the population were between 20 and $40 \mathrm{~m}$ and $17 \%$ between 10 and $20 \mathrm{~m}$. A small but significant number of krill was still present in the deeper layers at this time. This pattern was maintained until at least 02:00 h, but by 05:00 h the krill in the upper layers were moving down and by $08: 00 \mathrm{~h} 63 \%$ of the population was found between 60 and $80 \mathrm{~m}$.

During the winter cruise to the Clyde Sea, the daytime distribution was evenly spread between 60 and $150 \mathrm{~m}$. The population migrated into the upper layers between 16:00 and 19:00 $\mathrm{h}$ and 85 to $95 \%$ of individuals occurred above $60 \mathrm{~m}$ during the night, the majority between 20 and $40 \mathrm{~m}$; as in the summer, a small but significant number was present in the deeper layers at this time. Krill in the upper layers migrated downwards between 04:00 and 07:00 h, resulting in $93 \%$ of the population being found below $60 \mathrm{~m}$ by $07: 00 \mathrm{~h}$.

During the summer cruise in the Kattegat, almost the entire population occurred below $80 \mathrm{~m}$ during daytime. A fraction of the population was found in the upper layers at 23:00 and 02:00 $\mathrm{h}$, but a large proportion still remained below $80 \mathrm{~m}$. At 05:00 h, the entire population was once again below $80 \mathrm{~m}$ depth.

During the winter cruise in the Kattegat, krill remained below $80 \mathrm{~m}$ during the daytime $(12: 00 \mathrm{~h})$, but by $16: 00 \mathrm{~h}$ an upward migration was underway and $17 \%$ of the population occurred between 60 and $80 \mathrm{~m}$. Krill were more noticeable in the upper layers during the night than they were during the summer, possibly an effect of the higher numbers caught during the winter cruise (see Table 2). Nevertheless, the proportion of krill found in the upper layers was still relatively small compared with that below 80 m $(32 \%$ 
ひ 承
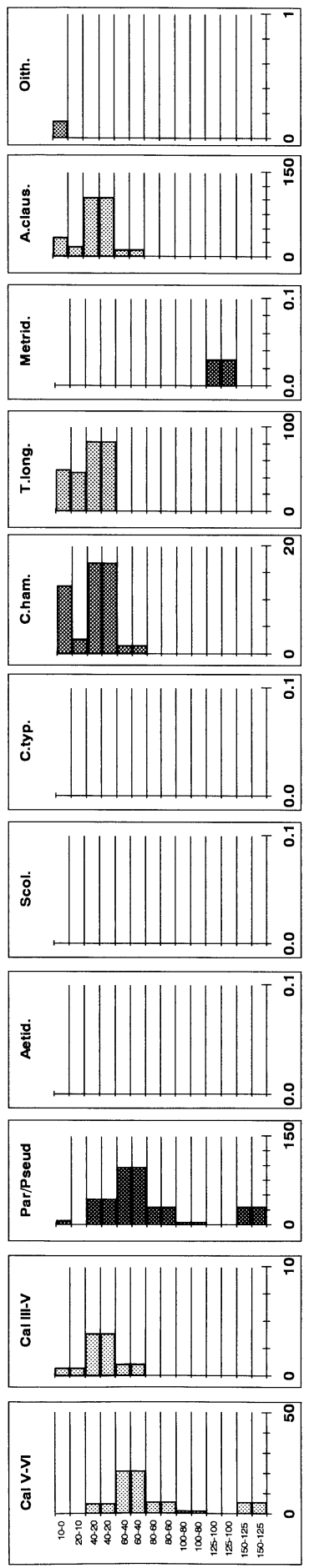

テ率
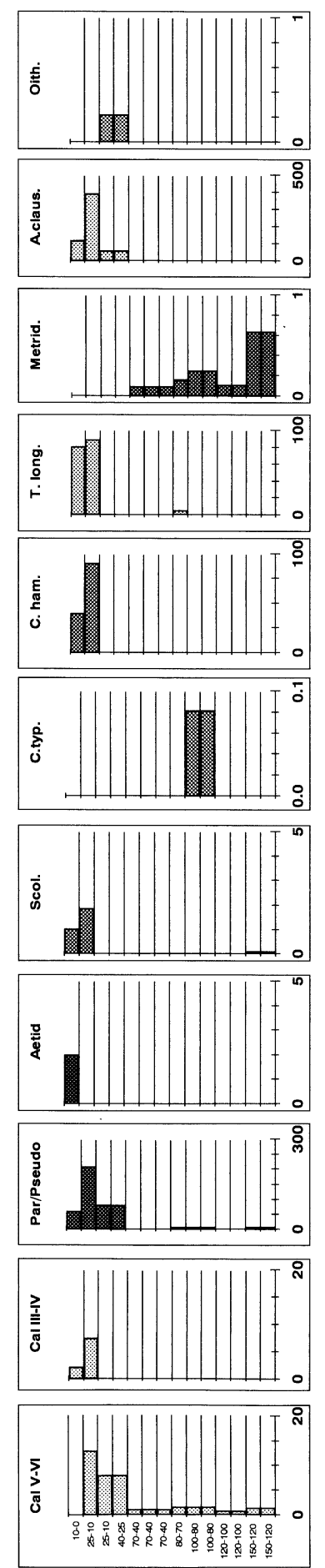

후옿
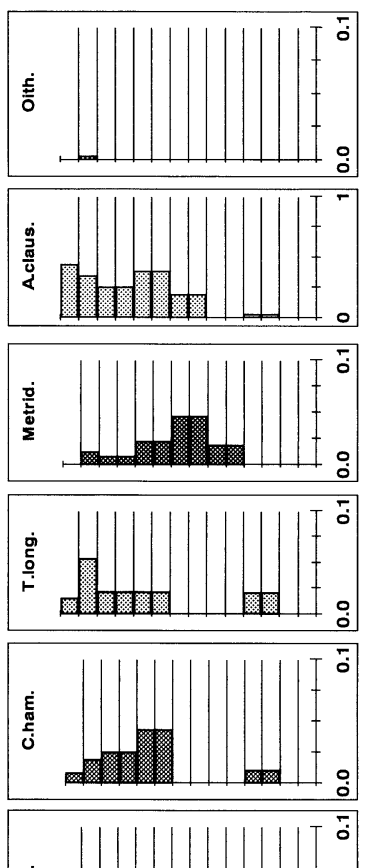

$\sum_{0}^{\dot{2}}$
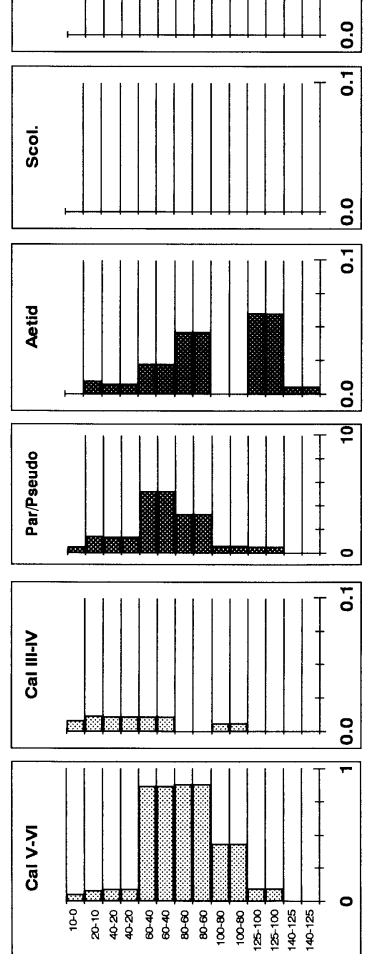

छ
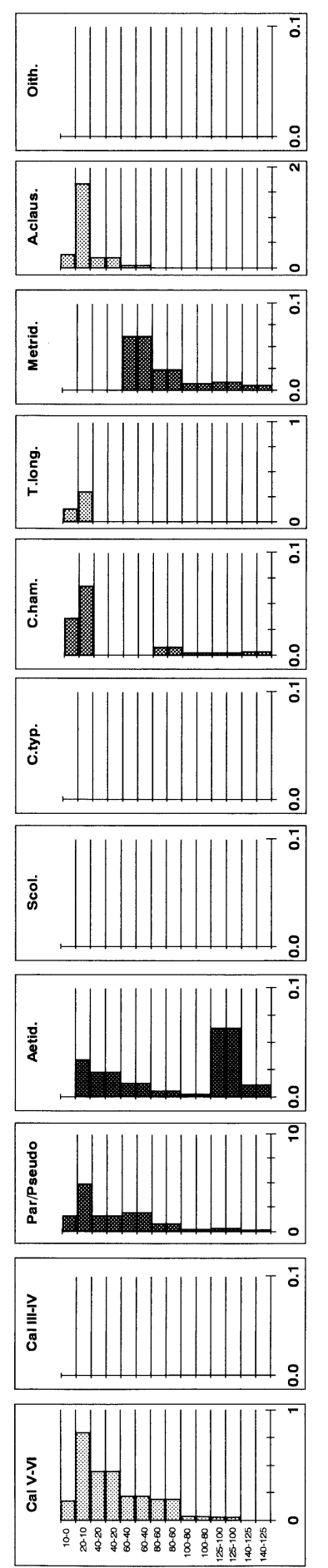

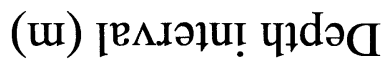

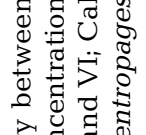

政

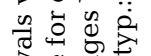

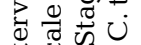

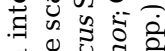

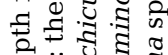

证

范范

告证

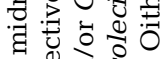

तु

일

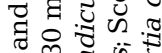

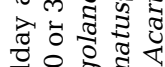

꿍

a. $0 \pi$

정 $\overrightarrow{2} \cong \pi$

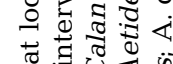

का

E

过

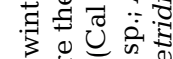

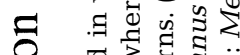

뭉

(⿹勹巳寸)

- 웡

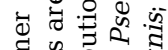

留 을

照

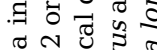

议

은

둥

을 웡

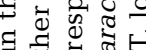

娄 32

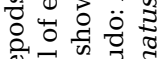

政

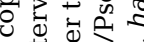

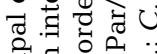

혈

a

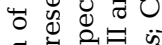

苨设

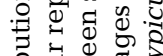

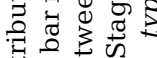

政

चु

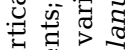

गे चี

त ह

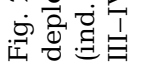




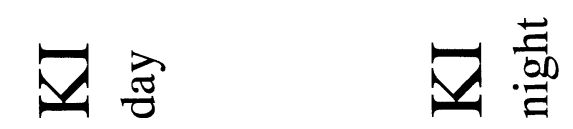
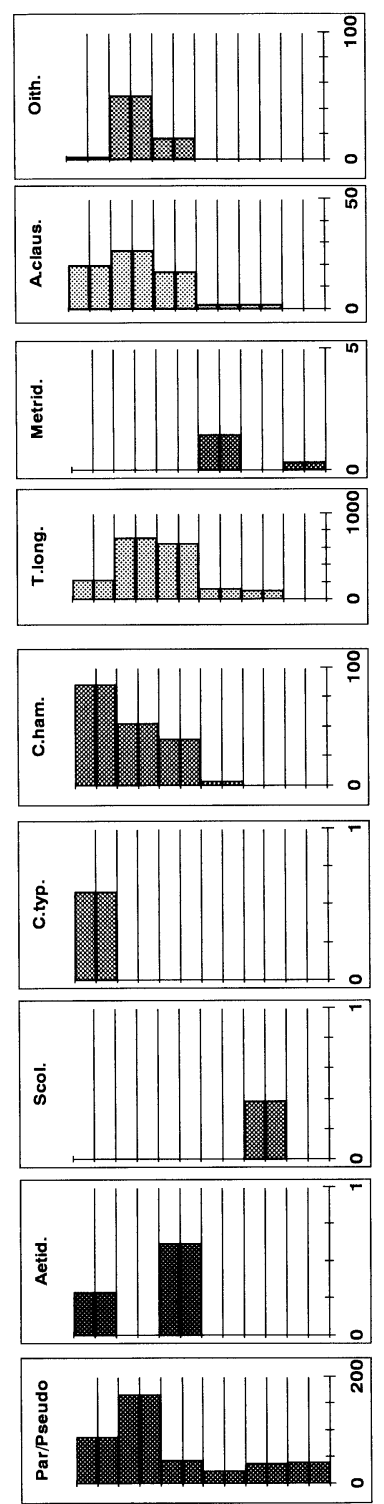

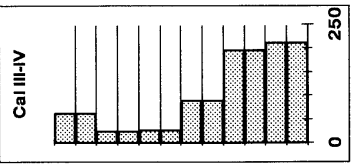

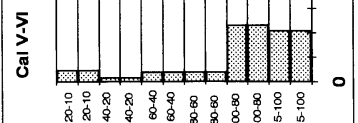

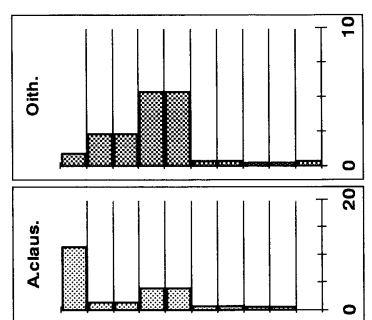
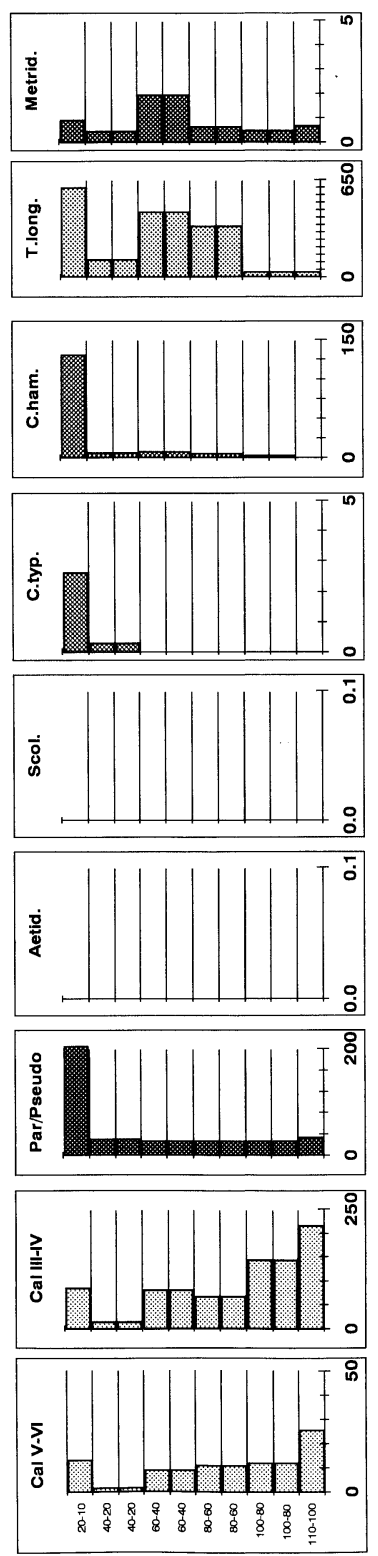

司总
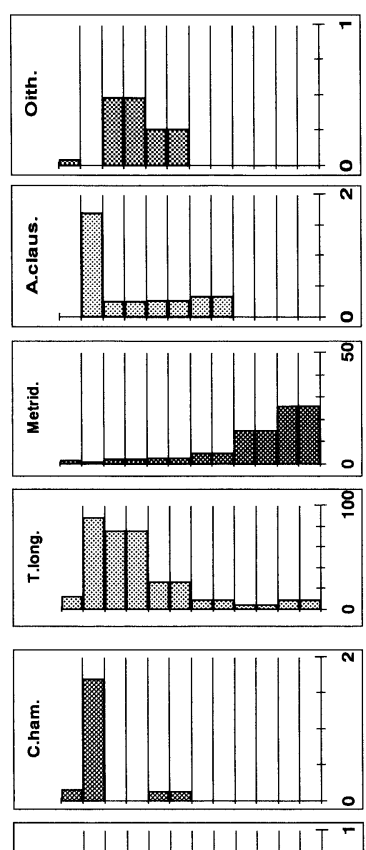

¿ุ̀
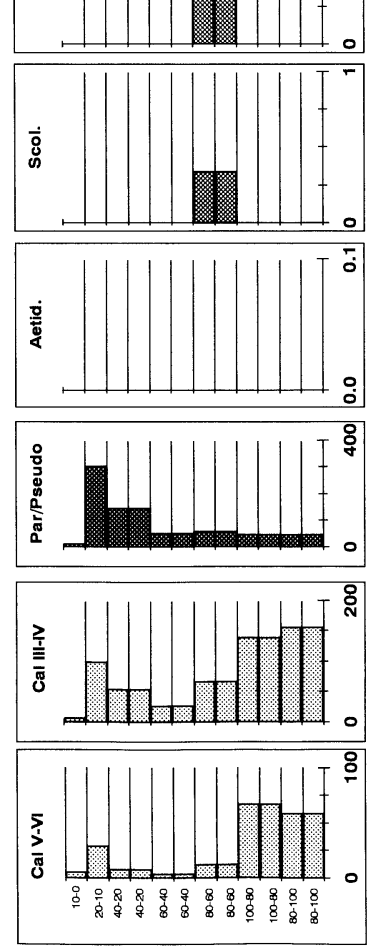

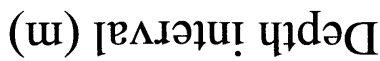


Table 1. Meganyctiphanes norvegica. Mean total length and standard deviation of different year classes in each sampling mission plus the mean total length and standard deviation of animals used in gut content analysis

\begin{tabular}{|lcc|}
\hline & $\begin{array}{c}\text { Mean total } \\
\text { length }(\mathrm{mm})\end{array}$ & $\begin{array}{c}\text { Standard } \\
\text { deviation }\end{array}$ \\
\hline Clyde Sea, summer & & \\
Year O & 16.5 & 1.48 \\
Year 1 & 34.5 & 1.21 \\
Year 2 & 39.5 & 1.75 \\
Gut-content animals & 38.0 & 2.53 \\
Clyde Sea, winter & & \\
Year 1 & 22.5 & 2.28 \\
Year 2 & 37.5 & 1.75 \\
Gut-content animals & 36.5 & 2.75 \\
Kattegat, summer & & \\
Year 0 & 13.5 & 0.94 \\
Year 1 & 28.5 & 1.48 \\
Year 2 & 33.5 & 1.75 \\
Gut-content animals & 31.2 & 2.80 \\
Kattegat, winter & & \\
Year 1 & 25.5 & 2.82 \\
Year 2 & 31.5 & 2.28 \\
Gut-content animals & 33.0 & 2.96 \\
\hline
\end{tabular}

Table 2. Meganyctiphanes norvegica. Range in concentrations (ind. $\mathrm{m}^{-2}$ ) of krill in net-deployments used for stomachand gut-content analysis and all other net-deployments in each sampling campaign

\begin{tabular}{|lcc|}
\hline Sampling campaign & $\begin{array}{c}\text { Concentration (ind. } \mathrm{m}^{-2} \text { ) } \\
\text { Stomach and gut } \\
\text { net-deployments }\end{array}$ & $\begin{array}{c}\text { Other net- } \\
\text { deployments }\end{array}$ \\
\hline Clyde Sea, summer & $7.0-19.7$ & $6.3-33.7$ \\
Clyde Sea, winter & $1.2-10.4$ & $0.7-31.4$ \\
Kattegat Sea, summer & $0.5-5.1$ & $2.7-18.8$ \\
Kattegat Sea, winter & $3.8-31.9$ & $1.7-156.4$ \\
\hline
\end{tabular}

against $65 \%$ ). Some krill were still in the upper layers at 06:00 h, but all had returned to below $80 \mathrm{~m}$ by 10:00 h.

Krill concentrations in net-samples used for stomachand gut-content analysis fell within the overall range of values observed during the cruises as a whole (Table 2), with the exception of the summer cruise in the Kattegat. Here concentrations were exceptionally low and rarely exceeded 5 ind $\mathrm{m}^{-2}$. Overall, krill was most abundant in the Kattegat in winter, when integrated concentrations were frequently above 20 ind. $\mathrm{m}^{-2}$. The summer cruise in the Clyde Sea also regularly found concentrations between 15 and 20 ind. $\mathrm{m}^{-2}$, but winter numbers were more variable and sometimes fell below 5 ind. $\mathrm{m}^{-2}$.

\section{Stomach and intestine fullness}

Indices of stomach fullness for krill caught in Net 1 (330 $\mu \mathrm{m}$ mesh) were compared with the combined Nets 2 to 9 (2 mm mesh) in order to determine the extent of cod-end feeding. A Mann-Whitney rank sum test found that the animals caught in Net 1 did have a significantly higher stomach content $(T=41323 ; \mathrm{n}=172,216$; $\mathrm{p}<$ 0.0001). A comparison of the different parameters of Net 1 and Nets 2 to 9 suggested that the higher fullness values for the stomachs from Net 1 resulted from the smaller mesh size (330 $\mu \mathrm{m}$ mesh), a generally longer duration of the tow (11 min compared with 6 min for Nets 2 to 9) and a larger volume of water sampled (an average of $740 \mathrm{~m}^{3}$ compared with $469 \mathrm{~m}^{3}$ for Nets 2 to 9). Since cod-end feeding was so evident in Net 1, only animals from Nets 2 to 9 were used for further analysis.

All net-samples from the Clyde Sea contained Meganyctiphanes norvegica with relatively full stomachs, and the median value for any particular sample was never lower than $50 \%$ and reached $100 \%$ in some cases (Fig. 5a,b). In both summer and winter, significant differences were found between samples taken at different times of day (summer: Kruskal-Wallis, $H=$ 11.9, df $=3, \mathrm{p}=0.0077$; winter: Kruskal-Wallis, $H=$ 14.1, $\mathrm{df}=3, \mathrm{p}=0.0028$ ) and at different depths (summer: Kruskal-Wallis, $H=20.4$, df $=6, \mathrm{p}=0.0034$; winter: Kruskal-Wallis, $H=16.1$, df $=6, \mathrm{p}=0.013$ ). A Dunn's test showed that, in summer, stomachs were significantly fuller at midnight than in the morning $(\mathrm{p}<$ $0.05)$ and at noon $(p<0.05)$ and also significantly fuller near the surface (0 to $40 \mathrm{~m}$ ) than in deeper layers (120 to $140 \mathrm{~m})$ ( $\mathrm{p}<0.05)$. In winter, stomachs were also fuller at night than in the morning (Dunn's test, p < 0.05). Stomachs of krill in the subsurface layers (20 to $40 \mathrm{~m}$ ) were significantly fuller than those directly below the surface (0 to $20 \mathrm{~m}$ ) (Dunn's test, $\mathrm{p}<0.05)$.

The median intestine fullness of the investigated Clyde Sea krill ranged between 12.5 and 100\% (Fig. 6a,b). Statistical tests showed no significant differences over time or depth in either summer or winter.

Stomach indices from krill taken in the Kattegat were generally lower than those from the Clyde Sea, with median values for fullness ranging between 25 and $75 \%$. Krill from the Kattegat also exhibited a completely different feeding pattern compared with those from the Clyde Sea. In summer, stomach fullness did not differ significantly over time or depth (Fig. 5c), but in winter significant differences over time (KruskalWallis, $H=21.6, \mathrm{df}=3, \mathrm{p}<0.0001$ ) and depth (KruskalWallis, $H=16.5, \mathrm{df}=4, \mathrm{p}=0.0024$ ) were found (Fig. 5d); Dunn's test showed that this was the result of animals having fuller stomachs at noon than in the morning $(\mathrm{p}<0.05)$ and in the intermediate layers than in the surface and deeper layers. 

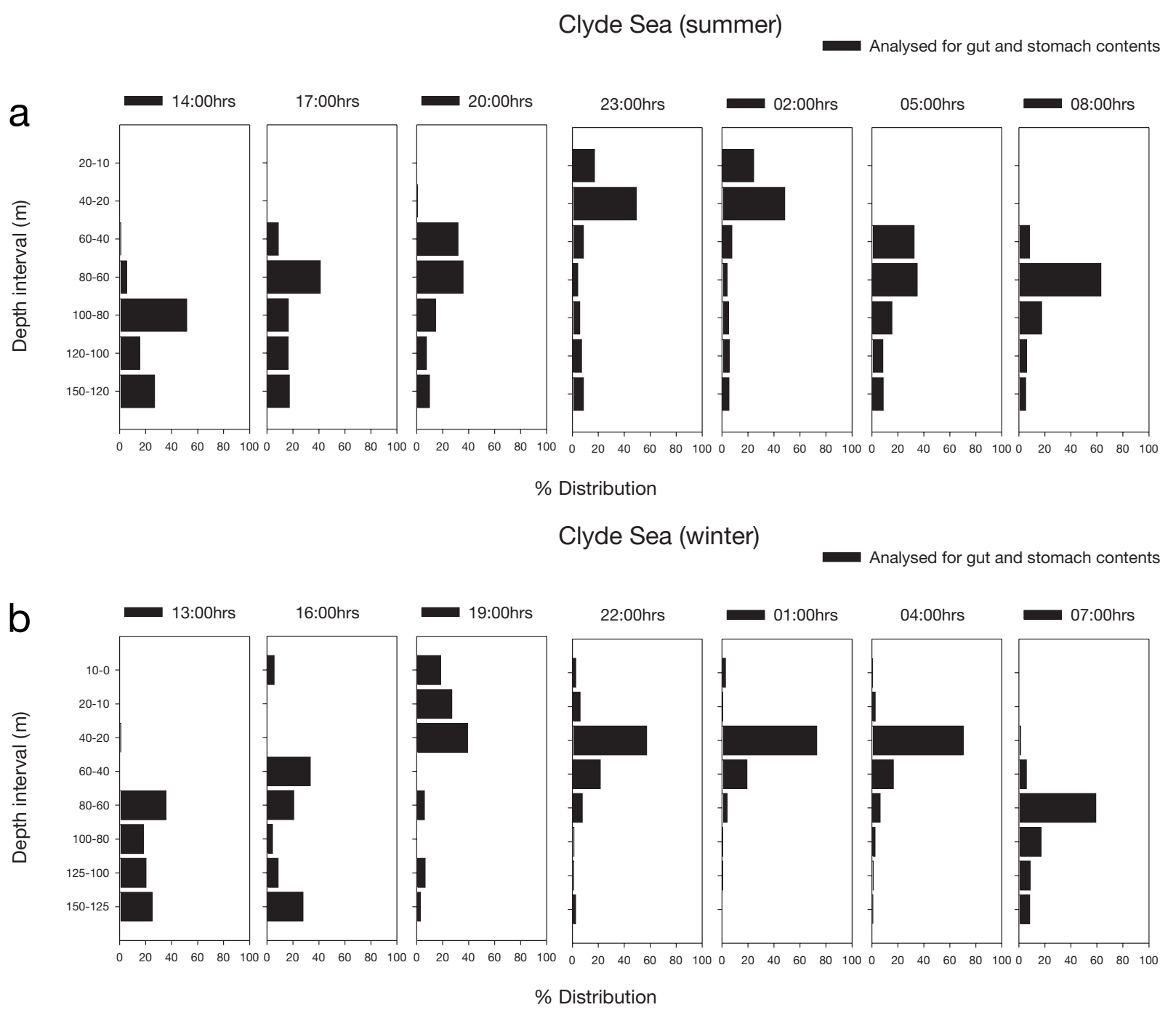

Fig. 4. (Above and facing page.) Meganyctiphanes norvegica. Vertical distribution of adults over a $30 \mathrm{~h}$ period, expressed as a percentage of the total number of animals within the water column of the Arran Deep (Clyde Sea) in (a) July 1996 and (b) February 1997, and of the Alkor Deep (Kattegat) in (c) July 1996 and (d) March 1997

As in the Clyde Sea, there were no significant differences over time or depth in the intestine fullness in the summer (Fig. 6C), but in the winter intestines were significantly less full in the morning (Kruskal-Wallis, $H=$ $54, \mathrm{df}=3, \mathrm{p}<0.0001$ ) than at all other times of day (Dunn's test, $\mathrm{p}<0.05$ ) (Fig. 6D).

\section{Stomach contents}

In most cases, the major part (80 to $90 \%$ in the Clyde and $70 \%$ in the Kattegat in summer) of the stomach contents was unidentifiable, but a much lower percentage $(20 \%)$ was unidentifiable in the Kattegat in winter. Scanning electron microscopy showed that a large amount of this unidentified matter consisted of frag- ments of centric diatoms. The relative abundance of the various identifiable components is shown in Table 3 and indicates a similar range of zooplankton and phytoplankton in the diet.

Copepod fragments and eggs, as well as remains of other crustaceans, were the major components in the stomachs of the Clyde Sea animals. Few copepod fragments and eggs were seen in winter, though there were still plenty of crustacean remains, and diatoms were also abundant. Euphausiid ommatidia were common in both seasons.

In the Kattegat, copepod remains dominated the stomach contents in summer, and copepod eggs, dinoflagellates and pine pollen were also common. In winter, copepod and other crustacean remains were again the dominant components. 

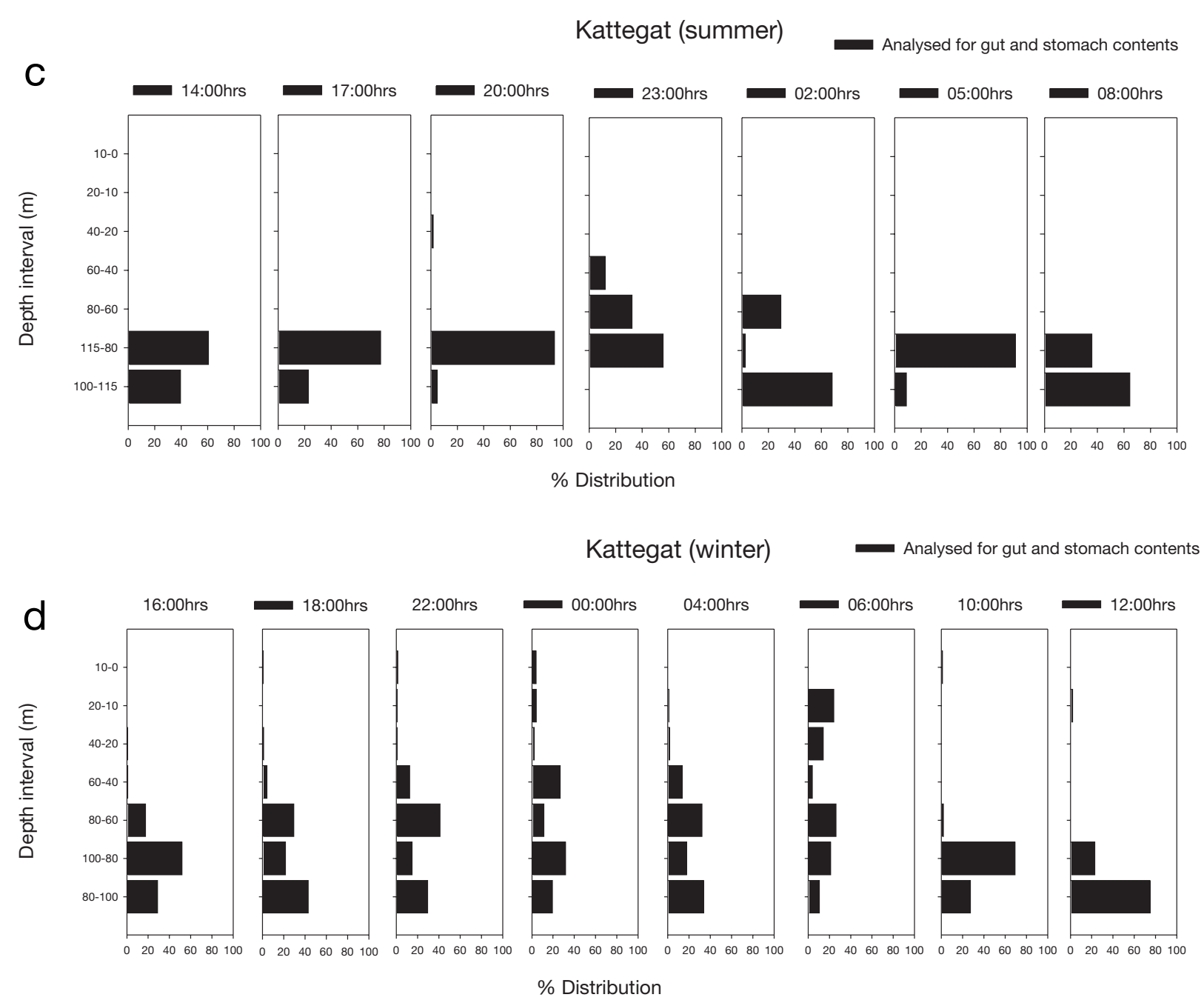

Fig. 4 (continued)

Copepod mandibles were the most easily identified objects and have been used to estimate the extent of copepod consumption. Fig. 7 shows the mean numbers of the 3 most common types of copepod mandibles (Temora, Para-/Pseudocalanus and Acartia in the Clyde; Temora, Para-/Pseudocalanus and Calanus in the Kattegat) over time and depth. Krill from the Clyde Sea consistently contained fewer mandibles than krill from the Kattegat. Some seasonal changes are evident, particularly the absence of Acartia in winter.

In the Clyde Sea in summer, more mandibles were found in the stomachs at night than during the day, especially near the surface. The same pattern was observed in winter though there were fewer mandibles altogether. In the Kattegat, relatively high numbers of mandibles were only found in krill from the deeper layers by day and night during the summer, but in winter there were more in the stomachs at night, particularly in the deeper layers.
Table 3. Meganyctiphanes norvegica. Average abundance of different food items in the stomachs of krill. Abundance was estimated in a semi-quantitative fashion: - not found , (+) very few, + few, ++ abundant, +++ very abundant

\begin{tabular}{|lcccc|}
\hline \multirow{2}{*}{ Food item } & \multicolumn{2}{c}{ Kattegat } & \multicolumn{2}{c|}{ Clyde Sea } \\
& Summer & Winter & Summer & Winter \\
\hline Diatom frustules & + & + & + & ++ \\
Dinoflagellates & ++ & $(+)$ & $(+)$ & + \\
Tintinnids & + & $(+)$ & + & $(+)$ \\
Pine pollen & ++ & + & + & + \\
Foraminiferans & $(+)$ & - & - & ++ \\
Crystal cones & + & + & ++ & ++ \\
(euphausiid eyes) & & & & \\
Crustacean remains & + & ++ & ++ & +++ \\
Copepod eggs & ++ & + & +++ & + \\
Copepod fragments & +++ & +++ & +++ & + \\
& & & & \\
\hline
\end{tabular}




\section{Multivariate analysis}

Classification multivariate analysis was employed to increase the objectivity of the comparison of trophic environment with stomach content samples. The analyses produced dendrograms that showed the level of similarity at which different samples were connected. It was then necessary to choose a level of simi-
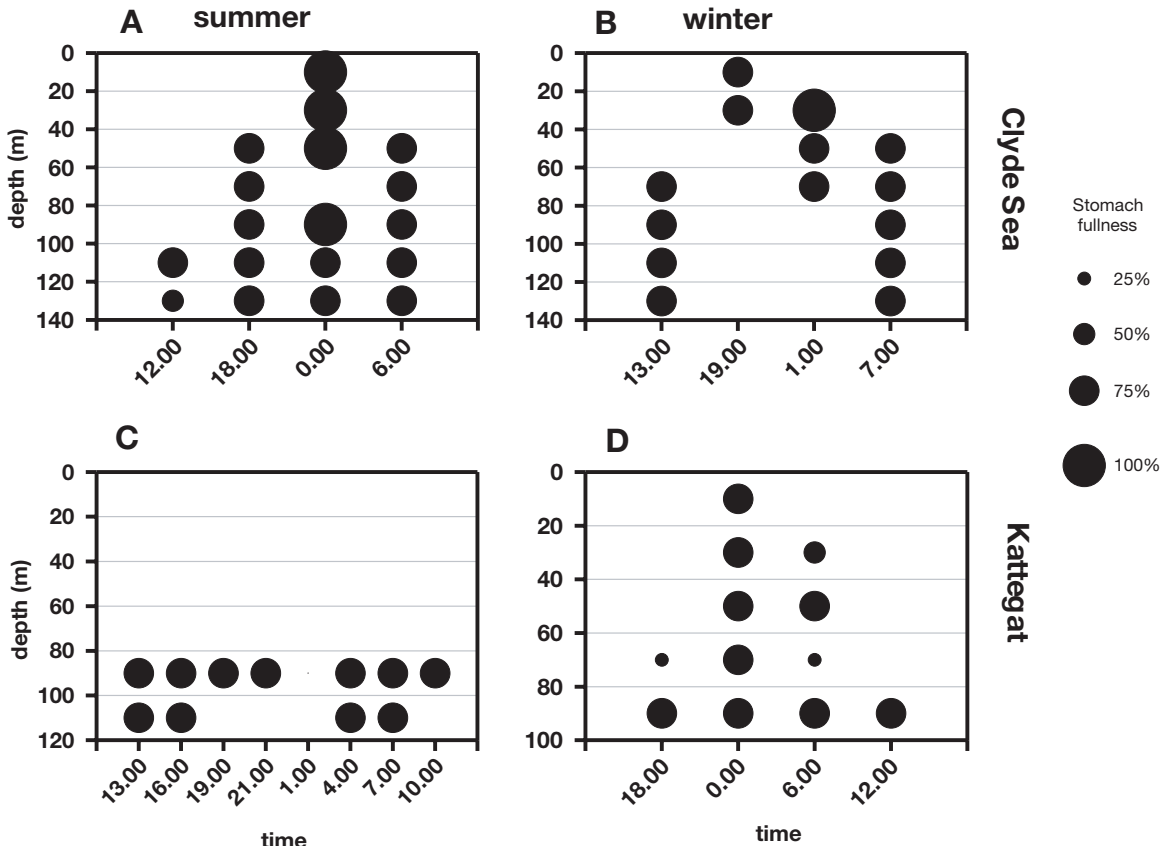

Fig. 5. Meganyctiphanes norvegica. Stomach fullness of northern krill in the Arran Deep (Clyde Sea) in (A) July 1996 and (B) February 1997, and in the Alkor Deep (Kattegat) in (C) July 1996 and (D) March 1997. Size of the dots represents median stomach fullness
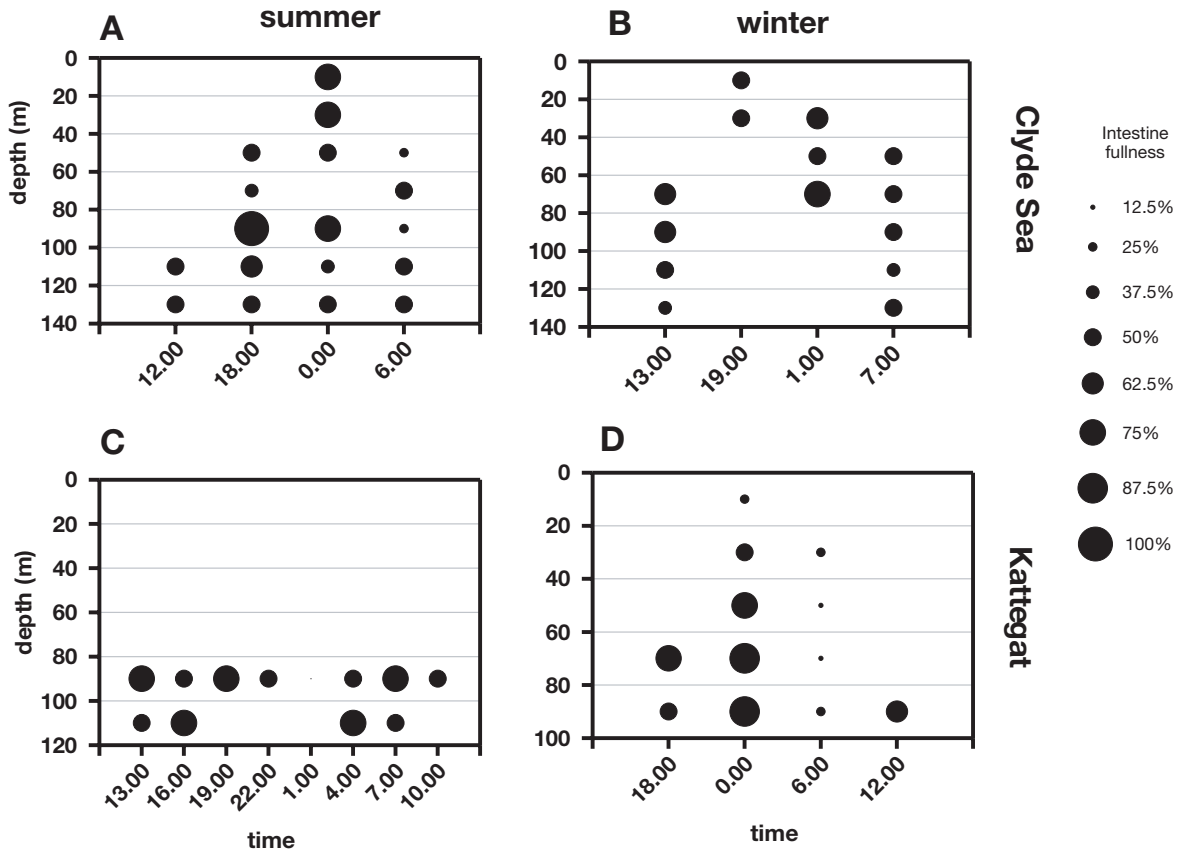

Fig. 6. Meganyctiphanes norvegica. Intestine fullness of northern krill in the Arran Deep (Clyde Sea) in (A) July 1996 and (B) February 1997, and in the Alkor Deep (Kattegat) in (C) July 1996 and (D) March 1997. Size of the dots represents median intestine fullness 
larity above which samples could be considered to be within the same group. There is no statistical method yet available to carry out this procedure objectively so a number of trial separations were initially carried out with the aim of revealing major similarities and differences in the data set. The Clyde Sea dendrogram was eventually separated at the $78 \%$ level and the Kattegat dendrogram at the $85 \%$ level (Figs. 8 \& 9). In both the Clyde Sea and the Kattegat, the separations produced a total of 6 groups (Tables 4 \& 5 respectively), although outliers were also apparent in the Clyde Sea analysis.

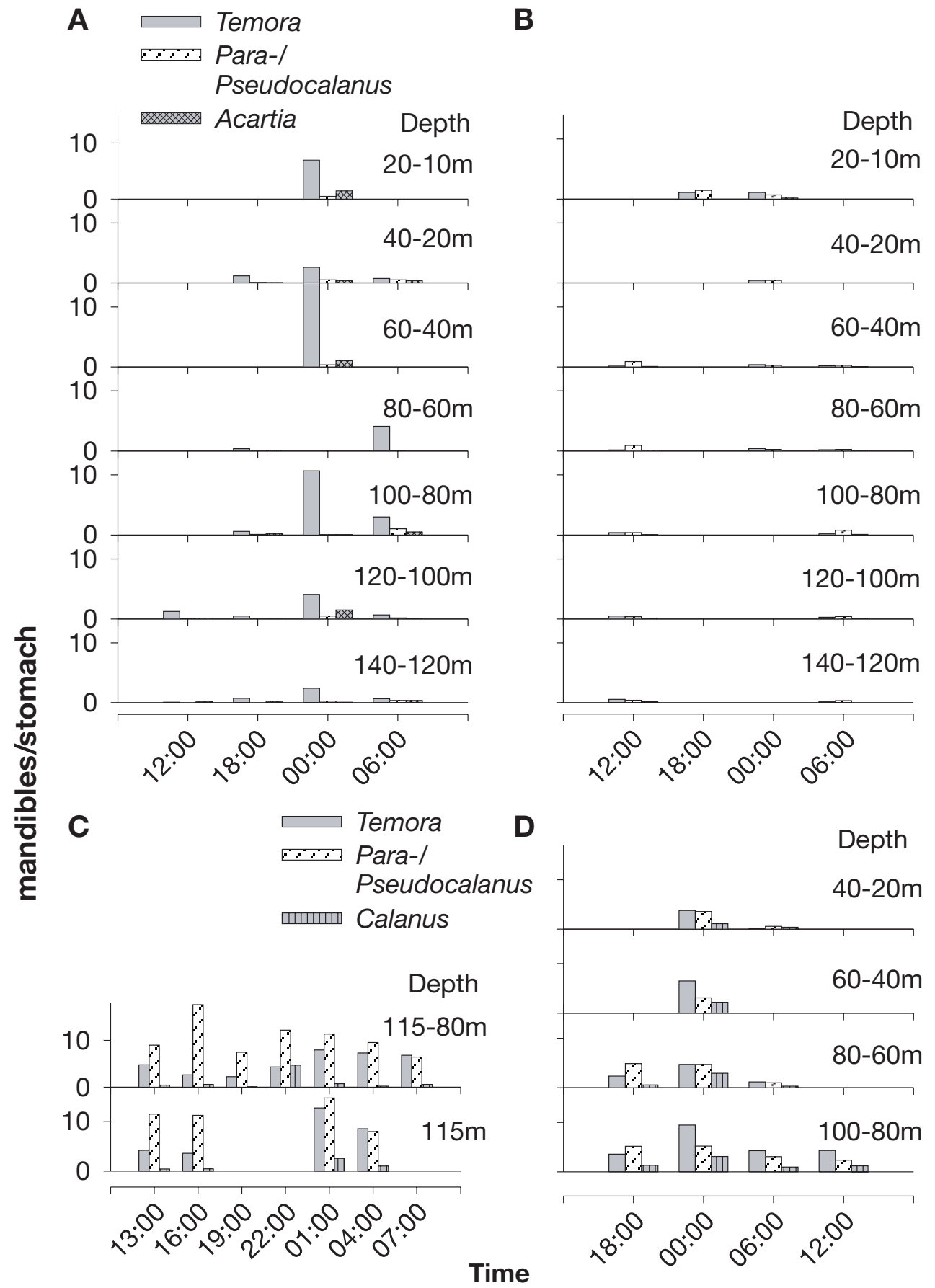

Fig. 7. The 3 most abundant species of copepods, in terms of mandibles, in the stomachs of northern krill (Meganyctiphanes norvegica) with respect to time and depth in the Arran Deep (Clyde Sea) in (A) July 1996 and (B) February 1997, and in the Kattegat in (C) July 1996 and (D) March 1997. Columns represent mean amount of copepod mandibles 


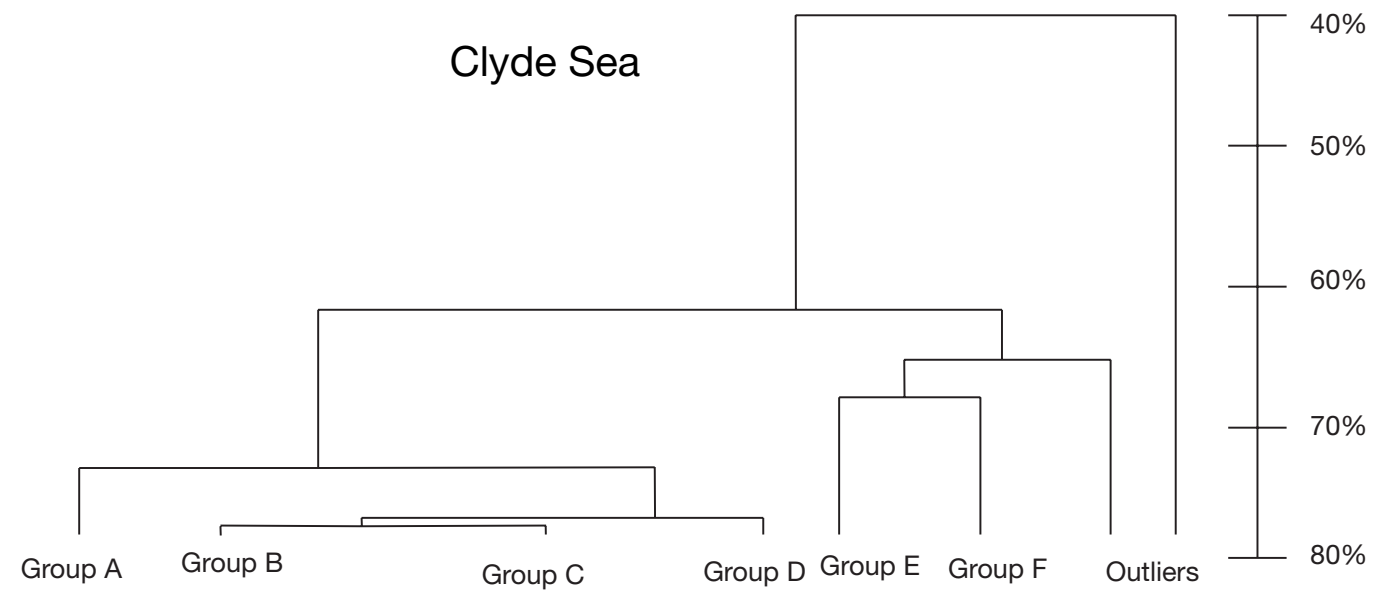

Fig. 8. Dendrogram of the similarity between samples (both from stomachs of Meganyctiphanes norvegica and the trophic environment) from the Clyde Sea with regards to their percentage composition of different copepod species (see Table 4 for codes used)

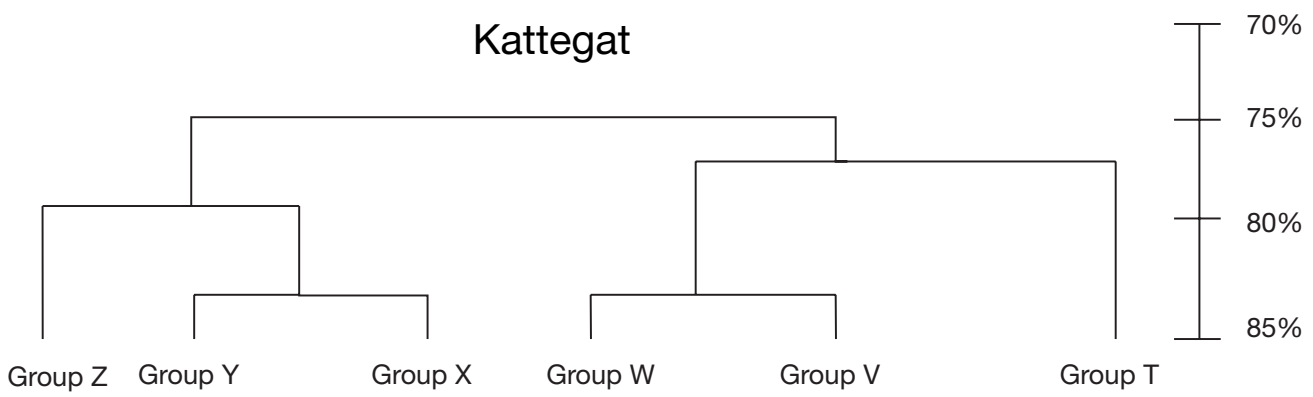

Fig. 9. Dendrogram of the similarity between samples (both from stomachs of Meganyctiphanes norvegica and the trophic environment) from the Kattegat with regards to their percentage composition of different copepod species (see Table 5 for codes used)

One of the major patterns apparent from the Clyde Sea analysis was that, in the summer, the stomach content samples fell into the same group as those trophic environment samples located towards the surface layers. This group, Group F, contained all but 2 of the stomach content samples found in the summer, the remainder being outliers (i.e. showing little similarity with any other samples). In the trophic environment, Group F contained the 0 to $10 \mathrm{~m}$ and 10 to $25 \mathrm{~m}$ and 60 to $80 \mathrm{~m}$ samples during nighttime and the 0 to $10 \mathrm{~m}$, 10 to $20 \mathrm{~m}$ and 20 to $40 \mathrm{~m}$ group during the daytime. The deeper trophic environment samples were a mix of Groups B, C and D, with no pattern being apparent. In winter, none of the stomach content samples fell into the same group as any of the trophic environment samples. There was little consistency in the groupings of the stomach content samples given that the 6 samples fell into 4 different groups (A, B, E and F). The grouping of the trophic environment samples, by contrast, was consistent, in that samples belonged to either Group C or Group D. Groups C and D share a similar- ity of $76 \%$ (see Fig. 8), just $2 \%$ less than the cut-off at $78 \%$, and so are relatively similar. This means that, in winter, the percentage composition of copepod species was relatively similar throughout the water column, indicating that the copepod community was well mixed. In the summer, the copepod community showed a vertical separation, with the percentage composition being very different in the surface layers compared with the deep.

The Kattegat showed similar patterns to those found in the Clyde Sea data set. In the summer, all stomach content samples fell into the same group (Group Y), which also contained the trophic environment samples taken from the surface layers (10 to 20, 20 to $40 \mathrm{~m}$ at night; 0 to 20,20 to $40 \mathrm{~m}$ during day). The trophic environment samples taken from the intermediate layers (40 to $80 \mathrm{~m}$ ) belonged to Group X, whilst those in the deepest layers (below $80 \mathrm{~m}$ ) belonged to Group W. In winter, stomach samples either fell into Group Y, as in summer, or into Group Z. Group Z was the closest group to Group Y in the 
Table 4. Classification groupings of trophic environment and gut content samples taken in the Clyde Sea in summer and winter

\begin{tabular}{|c|c|c|c|c|c|c|c|}
\hline & Group A & Group B & Group C & Group D & Group E & Group F & Outliers \\
\hline $\begin{array}{l}\text { Trophic } \\
\text { environment }\end{array}$ & & $\begin{array}{l}\text { Summer } \\
\text { Day } \\
80-100 \mathrm{~m} \\
100-120 \mathrm{~m}\end{array}$ & $\begin{array}{l}\text { Winter } \\
\text { Day } \\
0-10 \mathrm{~m} \\
10-20 \mathrm{~m} \\
20-40 \mathrm{~m} \\
40-60 \mathrm{~m} \\
100-125 \mathrm{~m} \\
\text { Night } \\
0-10 \mathrm{~m} \\
10-20 \mathrm{~m} \\
60-80 \mathrm{~m} \\
80-100 \mathrm{~m} \\
125-140 \mathrm{~m} \\
\text { Summer } \\
\text { Day } \\
40-60 \mathrm{~m} \\
\text { Night } \\
20-40 \mathrm{~m} \\
40-60 \mathrm{~m} \\
80-100 \mathrm{~m} \\
100-120 \mathrm{~m} \\
120-150 \mathrm{~m}\end{array}$ & $\begin{array}{l}\text { Winter } \\
\text { Day } \\
60-80 \mathrm{~m} \\
80-100 \mathrm{~m} \\
125-140 \mathrm{~m} \\
\text { Night } \\
20-40 \mathrm{~m} \\
40-60 \mathrm{~m} \\
100-125 \mathrm{~m} \\
\text { Summer } \\
\text { Day } \\
60-80 \mathrm{~m} \\
120-135 \mathrm{~m}\end{array}$ & & $\begin{array}{l}\text { Summer } \\
\text { Day } \\
0-10 \mathrm{~m} \\
10-20 \mathrm{~m} \\
20-40 \mathrm{~m} \\
\text { Night } \\
0-10 \mathrm{~m} \\
10-25 \mathrm{~m} \\
60-80 \mathrm{~m}\end{array}$ & \\
\hline Gut contents & $\begin{array}{l}\text { Winter } \\
\text { Day } \\
60-80 \mathrm{~m} \\
100-125 \mathrm{~m}\end{array}$ & $\begin{array}{l}\text { Winter } \\
\text { Night } \\
40-60 \mathrm{~m}\end{array}$ & & & $\begin{array}{l}\text { Winter } \\
\text { Day } \\
80-100 \mathrm{~m} \\
125-140 \mathrm{~m} \\
\text { Night } \\
60-80 \mathrm{~m}\end{array}$ & $\begin{array}{l}\text { Winter } \\
\text { Night } \\
20-40 \mathrm{~m} \\
\text { Summer } \\
\text { Day } \\
100-120 \mathrm{~m} \\
\text { Night } \\
10-20 \mathrm{~m} \\
20-40 \mathrm{~m} \\
40-60 \mathrm{~m} \\
100-115 \mathrm{~m} \\
115-140 \mathrm{~m}\end{array}$ & $\begin{array}{l}\text { Summer } \\
\text { Day } \\
120-135 \mathrm{~m} \\
\text { Night } \\
80-100 \mathrm{~m}\end{array}$ \\
\hline
\end{tabular}

dendrogram (see Fig. 9), with a $78 \%$ level of similarity, so the characteristic percentage compositions of both groups were not very different. In winter, none of the trophic environment samples fell into the same group as any of the stomach content samples because virtually all the trophic environment samples belonged to the same group (Group V). This pattern showed that the copepod community was relatively well mixed throughout the water column at this time of year, as in the Clyde Sea.

It is necessary to examine the percentage compositions of copepods in greater detail in order to determine what characterises each particular classification group. Figs. 10 \& 11 present the percentage composition of copepods in the trophic environment and in the stomach contents as pie-charts. The classification group letter is marked against the corresponding sample. In the Clyde Sea in summer (Fig. 10), it is apparent that Temora was the dominant copepod in Group $F$, the group including the surface layer sam- ples in the trophic environment and most of the stomach content samples. In the deeper layers of the trophic environment, a greater percentage of copepods were Calanus. In winter, Temora was virtually absent and Para-/Pseudocalanus were the dominant copepods throughout the water column. The species that varied most between depth intervals was Acartia and this constituted the main difference between Group C, where there was a relatively large percentage and Group D, where the percentage composition was less. The percentage composition pattern of copepods in the environment was never mirrored in any of the stomach content samples because Temora always remained a major dietary component. The variability in the copepods making up the remainder of the diet was probably the reason that the classification analysis did not group these samples in a consistent manner. For instance, in addition to Temora, Group E contained Acartia whilst Group A contained Calanus. 
Table 5. Classification groupings of trophic environment and gut content samples taken in the Kattegat in summer and winter

\begin{tabular}{|c|c|c|c|c|c|c|}
\hline & Group T & Group V & Group W & Group X & Group Y & Group Z \\
\hline $\begin{array}{l}\text { Trophic } \\
\text { environment }\end{array}$ & $\begin{array}{l}\text { Winter } \\
\text { Day } \\
80-100 \mathrm{~m} \\
10-20 \mathrm{~m} \\
20-40 \mathrm{~m} \\
40-60 \mathrm{~m} \\
60-80 \mathrm{~m} \\
\text { Night } \\
10-20 \mathrm{~m} \\
20-40 \mathrm{~m} \\
40-50 \mathrm{~m} \\
50-60 \mathrm{~m} \\
60-70 \mathrm{~m} \\
70-80 \mathrm{~m}\end{array}$ & $\begin{array}{l}\text { Winter } \\
\text { Day } \\
0-10 \mathrm{~m} \\
100-115 \mathrm{~m} \\
\text { Night } \\
80-100 \mathrm{~m} \\
100-110 \mathrm{~m}\end{array}$ & $\begin{array}{l}\text { Summer } \\
\text { Day } \\
80-100 \mathrm{~m} \\
\text { Night } \\
40-60 \mathrm{~m} \\
60-80 \mathrm{~m}\end{array}$ & $\begin{array}{l}\text { Summer } \\
\text { Day } \\
60-80 \mathrm{~m} \\
20-40 \mathrm{~m} \\
40-60 \mathrm{~m} \\
\text { Night } \\
10-20 \mathrm{~m} \\
20-40 \mathrm{~m}\end{array}$ & $\begin{array}{l}\text { Summer } \\
\text { Day } \\
0-20 \mathrm{~m}\end{array}$ & \\
\hline Gut contents & & & & 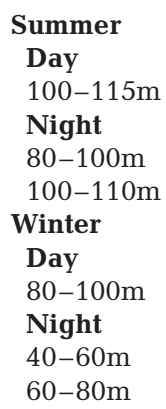 & $\begin{array}{l}\text { Winter } \\
\text { Day } \\
60-80 \mathrm{~m} \\
\text { Night } \\
20-40 \mathrm{~m} \\
80-100 \mathrm{~m}\end{array}$ & \\
\hline
\end{tabular}

In the Kattegat in summer (Fig. 11), Temora was a major component of Group Y, which included the majority of stomach content samples and near-surface trophic environment samples. However, Para-/Pseudocalanus were more evident in this group than the equivalent group in the Clyde Sea (i.e. Group F). The samples located at intermediate depths in the trophic environment (Group X) were characterised by a relative decrease in Para-/Pseudocalanus and an increase in Calanus compared with Group Y. The deep samples (Group W) were dominated by Calanus. In winter, the classification of all trophic environment samples into 1 group (Group V) reflected the fact that the whole water column was dominated by 3 species, Calanus, Temora and Para-/Pseudocalanus which were present in almost equal proportions. Metridia was the only other species to occur consistently in these samples but never in proportions $>10 \%$. The percentage compositions of Groups Y and Z, which contain the stomach content samples, are very similar to Group V with regard to the 3 major species. However, Groups Y and $\mathrm{Z}$ do not contain Metridia and generally have a Temora composition that is higher than any observed in the trophic environment samples. The major difference between Groups Y and Z is the fact that Group Y generally contains a small proportion of Acartia but Group $\mathrm{Z}$ does not.
Table 6. Meganyctiphanes norvegica. Total lipid, phytol and fatty alcohol composition of stomach contents ( $\left.\mu \mathrm{g} \mathrm{g}^{-1} \mathrm{ww}\right)$

\begin{tabular}{|c|c|c|c|c|}
\hline & \multicolumn{2}{|c|}{ Kattegat } & \multicolumn{2}{|c|}{ Clyde } \\
\hline & Summer & Winter & Summer & Winter \\
\hline $\begin{array}{l}\text { Total lipid (\%ww } \\
\text { of sample) }\end{array}$ & 1.5 & 1.8 & 1.4 & 1.6 \\
\hline Phytol & 2.0 & 7.5 & 26.8 & 4.1 \\
\hline $12: 0$ & 5.0 & 12.2 & 2.2 & 1.9 \\
\hline $14: 0$ & 261.7 & 50.7 & 2.8 & 4.9 \\
\hline i15:0 & 10.6 & 4.9 & 0.0 & 0.0 \\
\hline $16: 1(n-9)$ & 4.3 & 3.6 & 0.0 & 0.0 \\
\hline $16: 1(n-7)$ & 12.8 & 23.9 & 0.0 & 0.0 \\
\hline $16: 1(n-5)$ & 3.7 & 7.4 & 0.0 & 0.0 \\
\hline $16: 0$ & 697.0 & 173.5 & 4.7 & 5.0 \\
\hline $17: 0$ & 10.9 & 22.1 & 6.6 & 6.6 \\
\hline $18: 2(n-6)$ & 19.6 & 7.1 & 0.0 & 0.0 \\
\hline $18: 1(n-9)$ & 19.8 & 11.2 & 0.0 & 0.0 \\
\hline $18: 1(n-7)$ & 46.7 & 17.4 & 0.0 & 0.0 \\
\hline $18: 1(n-5)$ & 18.5 & 11.7 & 0.0 & 0.0 \\
\hline $18: 0$ & 35.7 & 14.2 & 2.0 & 2.5 \\
\hline $20: 1(n-11)$ & 8.2 & 5.1 & 0.0 & 0.0 \\
\hline $20: 1(n-9)$ & 78.6 & 118.6 & 0.0 & 0.0 \\
\hline $20: 1(n-7)$ & 8.9 & 0.0 & 0.0 & 0.0 \\
\hline $22: 1(n-11)$ & 193.2 & 207.5 & 11.9 & 14.2 \\
\hline $22: 1(n-9)$ & 21.6 & 16.5 & 6.5 & 5.0 \\
\hline $22: 1(n-7)$ & 6.4 & 7.4 & 0.0 & 0.0 \\
\hline $24: 1$ & 17.4 & 10.0 & 5.6 & 4.8 \\
\hline Total fatty alcohols & 1480.6 & 725.0 & 42.3 & 44.8 \\
\hline
\end{tabular}




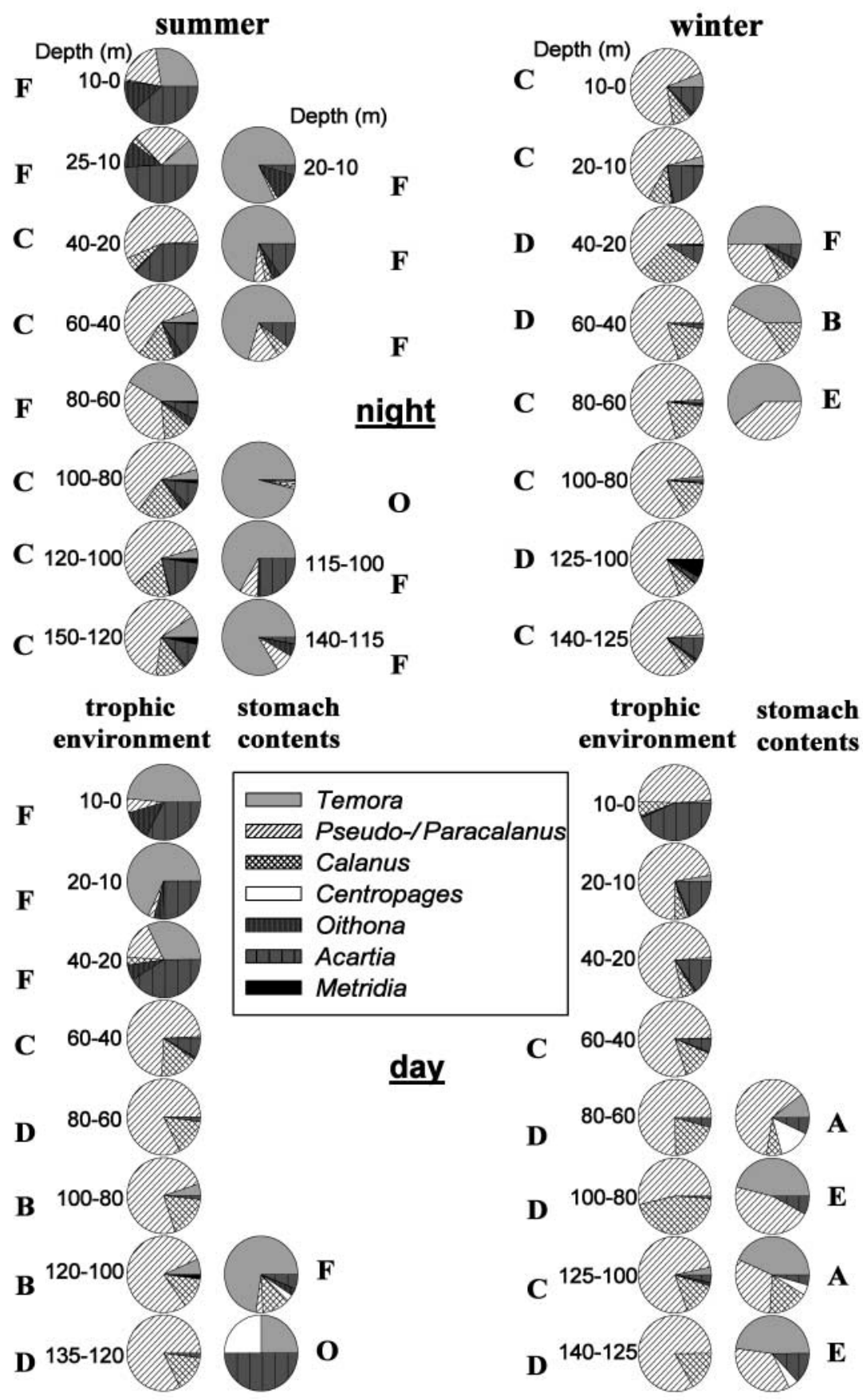

Fig. 10. Comparison of the copepods in the environment with mandibles in the stomachs of northern krill (Meganyctiphanes norvegica) in the Arran Deep (Clyde Sea) in July 1996 (summer) and February 1997 (winter). Values represent the numbers of each component relative to the total number in the sample. Labels are derived from Fig. 8 and Table 4

\section{Lipid composition of the stomach contents}

The total lipid content of the stomach samples ranged from 1.5 to $1.8 \%$ wet weight (Table 6$)$. The 3,7,11,15-Tetramethylhexadec-2-enol (phytol) levels were 3 to 13 times higher in the Clyde Sea summer krill $\left(27 \mu \mathrm{g} \mathrm{g}^{-1} \mathrm{ww}\right)$ than in krill from the Kattegat and Clyde Sea in winter (2 to $8 \mu \mathrm{g} \mathrm{g}^{-1}$ ) (Table 6). The prin- cipal lipid classes of Meganyctiphanes norvegica include triacylglycerol and polar lipid (Mayzaud et al.

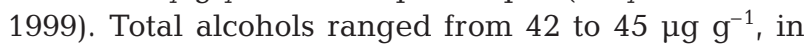
Clyde Sea krill. Total alcohol levels in the Kattegat krill

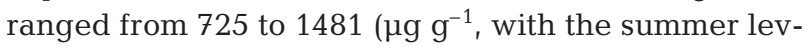
els being twice that found in the winter samples (Table 6). Long-chain monounsaturated fatty alcohols were 10-fold lower in the Clyde Sea krill $\left(24 \mu \mathrm{g} \mathrm{g}^{-1}\right)$ 

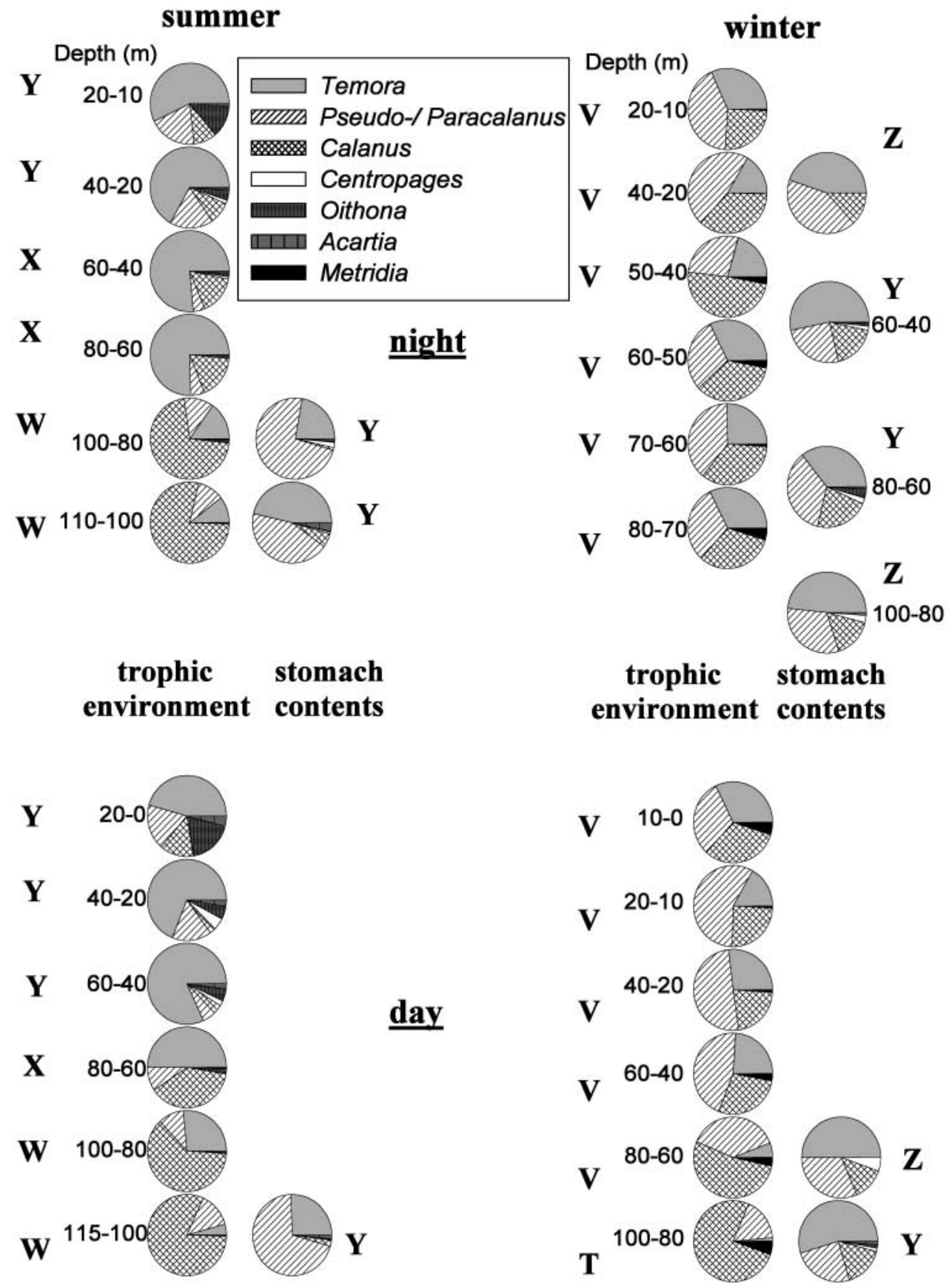

Fig. 11. Comparison of the copepods in the environment with mandibles in the stomachs of northern krill (Meganyctiphanes norvegica) in the Alkor Deep (Kattegat) in A, July 1996 and B, February 1997. Values represent the numbers of each component relative to the total number in the sample. Labels are derived from Fig. 9 and Table 5

compared with the Kattegat samples (334 to $365 \mu \mathrm{g}$ $\mathrm{g}^{-1}$ ). On a percentage basis, levels of long-chain monounsaturated fatty alcohols were similar in the Clyde (summer and winter) (53 to $57 \%$ ) and the Kattegat winter samples $(50 \%)$; the Kattegat summer samples, however, had lower levels $(23 \%)$. Relative levels of saturated fatty alcohols ranged from $273 \mu \mathrm{g} \mathrm{g}^{-1}$ $(37 \%)$ in the Kattegat winter to $1010 \mu^{-1} g^{-1}(81 \%)$ in the Kattegat summer, compared with 18 to $21 \mu \mathrm{g} \mathrm{g}^{-1}$ in the Clyde Sea samples.

Total fatty acids ranged from 4.3 to $9.6 \mathrm{mg} \mathrm{g}^{-1}$ in the Kattegat and from 8.0 to $9.3 \mathrm{mg} \mathrm{g}^{-1}$ in the Clyde krill (Table 7). Polyunsaturated fatty acids ranged from 38 to $42 \%$, branched fatty acids from 1.3 to $1.7 \%$ and long-chain monounsaturated fatty acids from 2 to $6 \%$. Levels of saturated fatty acids were 
Table 7. Meganyctiphanes norvegica. Percentage fatty acid composition of the stomach content

\begin{tabular}{|c|c|c|c|c|}
\hline & \multicolumn{2}{|c|}{ Kattegat } & \multicolumn{2}{|c|}{ Clyde } \\
\hline & Summer & Winter & Summer & Winter \\
\hline $12: 0$ & 0.6 & 0.1 & 0.5 & 0.6 \\
\hline 14:0 & 6.9 & 7.1 & 6.5 & 5.3 \\
\hline i15:0 & 0.5 & 0.4 & 0.3 & 0.2 \\
\hline a15:0 & 0.3 & 0.3 & 0.1 & 0.3 \\
\hline $15: 1$ & 0.2 & 0.3 & 0.1 & 0.1 \\
\hline $15: 0$ & 0.6 & 0.6 & 0.6 & 0.5 \\
\hline C16 pufa & 0.4 & 2.7 & 1.5 & 0.2 \\
\hline $16: 1(n-9)$ & 0.1 & 0.2 & 0.1 & 0.1 \\
\hline $16: 1(n-7)$ & 5.5 & 7.7 & 5.5 & 2.3 \\
\hline 16:1(n-5) & 0.4 & 0.5 & 0.4 & 0.4 \\
\hline 16:1(n-13)t & 0.2 & 0.4 & 0.2 & 0.1 \\
\hline 16:0 & 15.4 & 17.0 & 18.9 & 19.5 \\
\hline i17:0 & 0.3 & 0.4 & 0.4 & 0.3 \\
\hline a17:0 & 0.6 & 0.6 & 0.5 & 0.4 \\
\hline $17: 0$ & 0.4 & 0.4 & 0.4 & 0.4 \\
\hline $18: 4(n-3)$ & 2.8 & 1.0 & 1.6 & 1.0 \\
\hline $18: 2(n-6)$ & 2.3 & 1.0 & 1.4 & 2.8 \\
\hline 18:3(n-3) & 1.4 & 0.2 & 0.7 & 0.6 \\
\hline 18:1(n-9) & 16.3 & 11.7 & 10.5 & 16.2 \\
\hline 18:1(n-7) & 4.6 & 7.0 & 6.2 & 5.5 \\
\hline 18:1(n-5) & 0.5 & 0.5 & 0.4 & 0.3 \\
\hline 18:0 & 1.4 & 1.8 & 2.3 & 2.5 \\
\hline $20: 4(n-6)$ & 0.5 & 1.2 & 0.7 & 0.9 \\
\hline $20: 5(n-3)$ & 15.0 & 17.3 & 18.8 & 12.7 \\
\hline $20: 4(n-3)$ & 1.2 & 0.3 & 0.5 & 0.5 \\
\hline $20: 2(n-6)$ & 0.3 & 0.2 & 0.3 & 0.3 \\
\hline 20:1(n-13) & 0.4 & 0.2 & 0.4 & 0.3 \\
\hline 20:1(n-11) & 0.3 & 0.3 & 0.1 & 0.4 \\
\hline 20:1(n-9) & 0.6 & 1.9 & 1.8 & 3.6 \\
\hline $20: 1(n-7)$ & 0.4 & 0.5 & 0.6 & 0.5 \\
\hline $20: 0$ & 0.2 & 0.2 & 0.1 & 0.2 \\
\hline $21: 5(n-3)$ & 0.3 & 0.5 & 0.3 & 0.3 \\
\hline $22: 6(n-3)$ & 17.6 & 12.9 & 15.3 & 17.3 \\
\hline $22: 5(n-3)$ & 0.4 & 0.6 & 0.5 & 0.7 \\
\hline 22:1(n-11) & 0.3 & 0.7 & 0.2 & 1.2 \\
\hline $22: 1(n-9)$ & 0.1 & 0.2 & 0.3 & 0.3 \\
\hline $22: 1(n-7)$ & 0.1 & 0.1 & 0.1 & 0.1 \\
\hline $22: 0$ & 0.7 & 0.9 & 0.4 & 0.5 \\
\hline Sum saturated & 26.2 & 28.1 & 29.7 & 29.5 \\
\hline Sum monounsaturated & 29.9 & 32.3 & 27.2 & 31.5 \\
\hline Sum branched & 1.7 & 1.6 & 1.4 & 1.3 \\
\hline Sum polyunsaturated & 42.2 & 37.9 & 41.7 & 37.7 \\
\hline Total 20:1+22:1 & 2.2 & 3.8 & 3.6 & 6.4 \\
\hline Total fatty acids ( $\mathrm{mg} \mathrm{g}^{-1} \mathrm{ww}$ ) & 4.3 & 9.6 & 9.3 & 8.0 \\
\hline
\end{tabular}

similar with respect to site and season (26 to $30 \%$ ). Cholesterol was the major sterol in all samples, ranging from 66 to $77 \%$ (414 to $642 \mu \mathrm{g} \mathrm{g}{ }^{-1}$ ). Stanols ranged from 18 to $26 \mu^{-1} \mathrm{~g}^{-1}$ and a suite of phytosterols, including 24-nordehydrocholesterol, transdehydrocholesterol, desmosterol, brassicasterol, campesterol and sitosterol, was found in all samples (Table 8). Dinosterol (a specific biomarker for dinoflagellates) was found only in the Kattegat summer sample $\left(23 \mu \mathrm{g} \mathrm{g}^{-1}\right)$.

\section{DISCUSSION}

\section{Food items}

Microscopical and biochemical analysis of the stomach contents shows that Meganyctiphanes norvegica consumed a wide variety of food items and even fed on terrestrial material and other euphausiids. There are also signs that they fed on detritus, since high levels of branched fatty acids, which are characteristic of bacterial fatty acid profiles, were present in all krill stomach samples. A variety of stanols was also found in all samples. Bacteria are responsible for degradation of sterols to stanols. Normally, phytosterols are dealkylated rapidly to form cholesterol in the digestive gland (Virtue et al. 1993), and it is unlikely that they are degraded into stanols. It is more likely that the stanols found in the stomach originated from detrital matter and associated bacteria eaten by the krill. However, the krill stomach contains a larger variety of commensal if not endosymbiontic bacteria (Donachie et al. 1995), which may have been an additional source of the fatty acids analysed. Sitosterol and other C29 sterols, although present in some phytoplankton, have been reported to be markers for higher plants and hence for terrestrial input into ocean sediments (Volkman 1986, Nichols et al. 1989, Nichols 1990). Pine pollen was present in all stomach samples and was fairly abundant in Kattegat summer krill; correspondingly these had the highest levels of sitosterol of all samples.

The food items identified in the stomachs (Table 3) and the total lipid content of the stomach samples (Table 6) did not differ substantially between sites and seasons. However, microscopic analysis indicated that krill from the Clyde Sea were more herbivorous, while krill from the Kattegat predominantly fed on copepods. The biochemical analysis of the stomach contents supports this conclusion. Since the highest levels of phytol, which is the isoprenoid side-chain of chlorophyll and can be used to indicate photosynthetic biomass, was found in the Clyde Sea summer krill, phytoplankton must have been a major element in the diet at this time. This was also reflected in gut-pigment concentrations found in Clyde Sea krill $\left(4.2 \pm 1.1\right.$ $\left.\mathrm{gg}_{\text {ind }} .^{-1}\right)$ during the summer, which coincided with high chlorophyll levels in the surface waters during this cruise (Mayzaud pers. comm.). 
Table 8. Meganyctiphanes norvegica. Sterol stomach content ( $\left.\mu \mathrm{g} \mathrm{g}^{-1} \mathrm{ww}\right)$

\begin{tabular}{|c|c|c|c|c|}
\hline & \multicolumn{2}{|c|}{ Kattegat } & \multicolumn{2}{|c|}{$\begin{array}{c}\text { Clyde } \\
\text { Summer Winter }\end{array}$} \\
\hline 124-Nordehydrocholesterol & 18.9 & 18.5 & 16.9 & 12.7 \\
\hline 24-Nordehydrocholestanol & 1.4 & 2.6 & 3.9 & 3.1 \\
\hline Cis-Dehydrocholesterol & 3.1 & 4.3 & 0.0 & 1.6 \\
\hline Trans-Dehydrocholesterol & 27.0 & 14.6 & 20.5 & 19.6 \\
\hline Dehydrocholestanol & 11.7 & 6.2 & 5.3 & 3.3 \\
\hline Cholesterol & 430.0 & 642.0 & 436.2 & 414.4 \\
\hline Cholestanol & 7.6 & 6.7 & 8.8 & 9.3 \\
\hline Desmosterol & 29.3 & 47.7 & 27.7 & 14.8 \\
\hline Brassicasterol & 34.8 & 36.2 & 33.4 & 30.5 \\
\hline Brassicastanol & 5.6 & 6.2 & 1.6 & 1.8 \\
\hline 24-Methylenecholesterol & 8.5 & 20.5 & 2.4 & 2.5 \\
\hline Campesterol & 4.5 & 39.0 & 0.8 & 8.8 \\
\hline 23,24-Dimethylcholesta-5,22E-dien-3 $\beta$-ol & 9.0 & 0.0 & 4.6 & 16.8 \\
\hline Sisosterol & 18.7 & 0.0 & 4.3 & 6.5 \\
\hline 4,24-Dimethyl-5 $\alpha$-cholest-24,(28)-en-3 $\beta$-ol & $1 \quad 6.0$ & 0.0 & 3.6 & 0.0 \\
\hline Fucosterol & 9.3 & 0.0 & 0.0 & 1.9 \\
\hline Dinosterol & 23.2 & 0.0 & 0.0 & 0.0 \\
\hline
\end{tabular}

Fatty acids can be used as food chain markers. Surprisingly, very little of the traditional calanoid copepod markers (the long-chain monounsaturated fatty acids 20:1 and 22:1) (Falk-Petersen et al. 1987, Kattner \& Krause 1989) were present in any krill analysed, although it is evident from microscopic analysis that copepods and copepod eggs were major food items. Copepod eggs have similar fatty acid and sterol profiles to the copepods themselves, although the eggs have negligible levels of the long-chain monounsaturated fatty acids and fatty alcohols. The fatty acid profiles of copepod eggs and of other non-calanoid crustaceans seem, to a large degree, to have obscured the copepod markers in the stomach by diluting these markers. However, cholesterol, which is rare in phytoplankton but makes up most of the sterol component in copepods, copepod eggs and other crustaceans, was the major sterol in all samples (66 to $77 \%$ ). Collectively these food items made up a major portion of the diet as identified in the present analyses. Fatty alcohols are derived from the wax-ester component of the lipid in many copepods, whereas only trace levels of fatty alcohols are found in phytoplankton. Profiles of fatty alcohols in Kattegat krill were similar to those of copepod wax esters, with high levels of saturated and longchain monounsaturated fatty alcohols. The fatty alcohol levels in the Kattegat summer krill were double those found in winter. The Clyde Sea krill had around 30 times lower fatty alcohol levels than Kattegat krill. These low levels of fatty alcohols were similar during both seasons in the Clyde Sea krill.

It appears from these data that calanoid copepods made up a much greater proportion of the krill diet in the Kattegat than in the Clyde Sea. In line with this, depth-integrated copepod biomass in the water column was generally higher in the Kattegat than in the Clyde Sea (Fig. 1a,b) whereas chlorophyll a levels were much higher in the Clyde Sea than in the Kattegat (see Matthews et al. 2000). With respect to their omnivorous feeding behaviour, therefore, it appears that northern krill can switch between herbivory and carnivory quite opportunistically, depending on food availability, a characteristic that has been remarked upon in many previous studies on Meganyctiphanes norvegica (e.g. MacDonald 1927, Fisher \& Goldie 1959, Mauchline 1960, Sameoto 1980, Klages 1983, Onsrud \& Kaartvedt 1998). Feeding plasticity is not exclusive to this species but is also reported in euphausiids like Antarctic krill, Euphausia superba (Atkinson \& Snyder 1997, Saborowski \& Buchholz 1999), E. pacifica off the west coast of North America (Ohman 1984) and E. lucens in the Benguela current off South Africa (Gibbons et al. 1991, Stuart \& Huggett 1992, Gibbons 1993). Nevertheless, amongst euphausiid species, the food spectrum of $M$. norvegica is particularly broad (Sameoto 1980, Fevolden 1982), and several authors have concluded that it may need this variety in order to satisfy its nutritional requirements (Fisher \& Goldie 1959, Sameoto 1980, McClatchie 1985). Sameoto (1980) suggested that $M$. norvegica migrates to the surface even if food is abundant in deeper layers in order to reach different food sources. The ability to feed on such a varied diet may be one of the reasons for $M$. norvegica being a major and successful component of zooplankton communities in many areas with very different trophic regimes and environmental conditions.

\section{Ingestion rates}

The indices of stomach fullness suggested that there was a different feeding pattern in krill from the Clyde Sea compared with krill in the Kattegat. Significant differences were found between different times of day in the Clyde Sea, with the highest values at night; there were no differences between different times of the day in the Kattegat. In other words, whereas ingestion rate appeared to have a diel rhythm in the Clyde Sea, no such pattern was apparent in the Kattegat. These results fit with our information on the food environment. In the Clyde Sea, the main food supply, both phytoplankton and copepods (Fig. 1a), was concen- 
trated near the surface, so the night-time vertical migration into these layers increased the potential food intake. In the Kattegat, where the diet was mostly carnivorous, the copepod biomass was evenly distributed through the water column (Fig. 1b), making food available throughout the day/night cycle.

One possible conclusion is that ingestion rate is purely dependent on food availability and that krill feeding activity is constant through the day/night cycle. This conclusion would generally be in line with that of most other studies on the feeding behaviour of Meganyctiphanes norvegica (e.g. Mauchline 1960, Sameoto 1980, Båmstedt \& Karlson 1998, Onsrud \& Kaartvedt 1998). However, gut clearance rates are affected by, amongst other things, ambient food concentrations (Geller 1975, Arashkevich 1977, Murtaugh 1981), temperature (Fedorenko 1975, Murtaugh 1981, Marchant \& Hynes 1981) and prey type (Fedorenko 1975), so conclusions regarding ingestion rates cannot be derived from information on gut fullness alone. Krill in cold, deep water may retain food in their stomachs much longer than actively feeding animals in warmer surface layers. Therefore, the approach taken in this study was to combine gut-fullness information with a species-specific analysis of stomach contents in order to determine the timing and location of feeding activity. The remainder of this discussion will consider the insights gained from taking this comprehensive approach.

\section{Selection of copepod prey}

Clyde Sea krill generally consumed the same type of copepods as those in the Kattegat. However, the relative composition of these species in the gut contents did differ between the 2 sites. In both the Clyde Sea and Kattegat, Temora and Para-/Pseudocalanus made up the majority of the mandibles found in the stomach contents. However, whereas Temora dominated the gut contents of Clyde Sea krill, Para-/Pseudocalanus was more dominant in the gut contents of Kattegat krill. This is in contrast to the relative levels of abundance of each species found in the environment, since Para-/Pseudocalanus made up the largest proportion of the Clyde Sea copepod community and Temora was by far the most common copepod in the Kattegat. The ingestion rates of these 2 very similar prey species do not reflect relative abundance levels in the environment, suggesting selectivity in feeding behaviour. One may speculate that one of these species is the preferred (most profitable) prey type and consumed in preference to the other until concentrations fall below a critical level and a 'switch' takes place to the less preferred prey type. Although Para-/Pseudocalanus was dominant in the Clyde Sea area, its absolute abundance was lower in this site than in the Kattegat ( $\sim 4000$ and $\sim 6000$ ind. $\mathrm{m}^{-2}$ respectively). It follows that, in the Clyde Sea, concentrations of Para-/Pseudocalanus were below a critical level, and the krill focussed on Temora as the next most profitable prey item. In the Kattegat, concentrations of Para-/Pseudocalanus were above a critical level making it the optimal prey species on which to focus feeding efforts. Foraging theory puts forward that the concentration of the less preferred prey type (Temora) is no longer relevant when a sufficient concentration of the preferred prey type is present (see review by Krebs \& McCleery 1984). Therefore, even when concentrations of Temora far exceeded those of Para-/Pseudocalanus, as was seen in the Kattegat, it was not consumed in any great quantity.

Evidence that euphausiids may be selective when foraging on copepod prey comes from Gibbons et al. (1991), who found that Euphausia lucens consumed smaller copepod species (e.g. Oithona) at greater than ambient levels, and Stuart \& Huggett (1992), who showed that this same species selected slow, continuous swimmers as opposed to fast, intermittent swimmers. There is little difference in size between Para/ Pseudocalanus and Temora, but differences in swimming behaviour of Paracalanus parvus and Temora longicornis were noted by Hardy \& Bainbridge (1954). Whereas $P$. parvus exhibited an irregular zig-zagging path when swimming, $T$. longicornis showed a more direct and relatively faster swimming behaviour. Such differences may affect the detection and capture rates of these species by krill and hence their relative profitabilities as prey types. This may be further investigated by laboratory feeding experiments using mixtures of these 2 prey species.

\section{Multivariate analysis}

In both the Clyde Sea and Kattegat it is evident that there was a marked difference between the relative abundance of various copepod species ingested and in the ambient plankton. In summer in the Clyde Sea, Temora and Acartia were dominant in stomachs both day and night, but these species were only abundant in the surface layers. Indeed, in multivariate analyses, the percentage composition of copepods in some of the stomachs was so similar to the composition in the surface layers that they were classified within the same group. The classification of the deeper trophic environment samples into different groups indicated that the composition of the copepods in the deeper layers was quite different from those found at the surface. With respect to feeding, therefore, the krill appear to con- 
sume copepods at a rate that reflects the ambient concentrations of prey at the surface more than in the deep. There was a different situation in the Clyde Sea in winter, since there was little change in the composition of copepods throughout the whole water column, but the composition of the stomachs showed little similarity to situations found in any part of the trophic environment.

Almost an identical pattern was found in the Kattegat. In summer, the composition of the copepod community in the surface was different to the deeper layers, but similar to that found in the stomachs. In winter, copepod compositions were similar throughout the whole water column, but different from that found in any of the stomachs. One difference from the Clyde Sea situation was that many of the winter stomach samples belonged to the same group as the summer stomach samples (Group Y). Those that belonged to a different group (Group Z) also shared a high level of similarity $(78 \%)$ with the other stomach samples. In this instance it seems that the krill maintained a similar intake of different copepod species even when the relative concentrations of these species in the environment had changed with season.

\section{Rhythms in feeding activity}

In both the Clyde Sea and Kattegat, the major part of the krill population was observed to migrate from deeper layers occupied during the daytime to the surface layers at night. For the Clyde Sea, this means that the krill left an impoverished trophic environment occupied during the daytime to enter an environment rich in phytoplankton and copepods at night. It is to be expected, therefore, that feeding at the surface at night will always result in the highest ingestion rates, because food concentrations are higher there than in the deeper layers. In the Kattegat, copepods made up the major part of the trophic environment, and their combined biomass was evenly spread through the water column. This means that the vertical migration behaviour of krill does not result in them experiencing a quantitative difference in the food that is available. However, the qualitative results from the summer show that stomach contents were very similar in composition to values found in the surface layers of the trophic environment, indicating that krill feed in the surface layers at night.

Interpretation of the results becomes more intricate when considering the feeding activity of krill in the deeper layers occupied during the daytime. The results of the multivariate analyses as well as the data in Figs. $10 \& 11$ indicate that, during the summer, the stomach contents of krill in whatever layer they were found remained relatively similar even though they moved between strata with markedly different copepod compositions. If feeding continued during daytime in the deeper layers, and all copepod prey were equally vulnerable, then a change in the copepod composition of the guts during daytime would be expected. Fig. 1a shows that the biomass of copepods in the layers occupied by krill during the daytime in the Clyde Sea (60 to $100 \mathrm{~m}$ ) was almost negligible, indicating that little copepod consumption would have been possible. The fact that the stomachs still contained mandibles suggests that the mandibles of the copepods eaten at the surface during night-time were being retained. Copepod biomass levels were larger in the deeper layers of the Kattegat making copepod consumption more possible. The similarity of day- and night-time stomach compositions nevertheless suggests that, as in the Clyde Sea, there was low daytime feeding activity and the mandibles that were present in the stomach had been consumed the previous night. This is supported, for winter at least, by the fact that stomach fullness did not vary significantly with time of day but intestinal fullness was significantly lower in the morning $(06: 00 \mathrm{~h})$ than at any other time. If feeding did continue through the morning period, then it would be expected that matter would continue to flow through the intestine and that the levels of fullness would remain relatively constant. The emptying of the intestine, however, suggests that food was being retained in the stomach whilst digestion continued in the intestine.

Båmstedt \& Karlson (1998) found that Meganyctiphanes norvegica did not retain mandibles in the stomachs when presented with a constant supply of copepod prey. By contrast, Murtaugh (1984) found that when mysids fed on a diet of copepods were subsequently starved, mandibles were retained for over $3 \mathrm{~d}$. For krill in the Clyde Sea, daytime descent to the deeper layers resulted in virtual starvation, and so mandible retention would not be surprising. However, in the case of Kattegat krill, any starvation that resulted in mandible retention would only be the result of an internal feeding rhythm, since copepods were relatively abundant in the deep layers occupied during the daytime. An internal feeding rhythm was not apparent in incubation experiments carried out on $M$. norvegica by Båmstedt \& Karlson (1998). Nevertheless, one must take into account the disturbance caused by handling in the laboratory, which may prevent krill from receiving a number of important external cues which co-ordinate the behaviour.

Although a number of studies have noted periodic food uptake in Meganyctiphanes norvegica (Sameoto 1980, Buchholz et al. 1995, Onsrud \& Kaartvedt 1998), this is the first to indicate that this may result from a diel rhythm in feeding activity. Bollens \& Stearns 
(1992) have demonstrated the adaptive value of feeding rhythms in copepods as a response to predators. They found that copepods in the presence of fish have significantly lower levels of gut fullness. The reason, it was argued, is a reduction in visibility to predators due to a less darkened (i.e. not completely filled) digestive tract. It is unlikely that, in krill, any reduction in feeding activity during daytime is a response to lower visibility, since they occupy the deeper, darker layers at this time of day. Nevertheless, reducing feeding activity will also reduce levels of locomotory activity, which may attract the attention of predators that feed in the deeper layers, such as cod. Klages (1983) for instance found that northern krill perform somersaults in order to home in on food items, a behaviour that is likely to cause pressure waves that would be detectable by fish sensory organs. Therefore, despite krill's opportunistic choice of food items, predation pressure may influence when and where the food is consumed.

Acknowledgements. This paper is dedicated to the memory of Renate Haass, particularly in recognition of sharing her vast knowledge of euphausiids with Sandra Lass. We would like to thank the following people for their assistance in collecting net samples and/or support during the sampling campaign: E. Albessard, S. Bröhl, C. Buchholz, J. Cuzin-Roudy, S. Dallot, P. David, K. Grau, O. Guerin, M. Hatherell, J.-P Labat, D. Müller-Navarra, P. Schumann, S. Sabini, R. Saborowski and M. Salomon. We would like to acknowledge the support and efficiency of the crew of the RV 'Heincke'. Thanks also to P. Nichols for his expertise in GC-MS interpretation and to R. Saborowski for his help with data analysis. Prof. Rick Phleger is gratefully acknowledged for his constructive comments on this manuscript. This project was funded by EU-MAST III (MAS3-CT95-0013), the PEP Programme. G.T. was additionally funded by an NERC MSTB fellowship entitled 'Advective ecology of zooplankton in the Clyde Sea' (GST/59818MS).

\section{LITERATURE CITED}

Anraku M, Omori M (1963) Preliminary survey of the relationship between feeding habit and the structure of the mouth parts of marine copepods. Limnol Oceanogr 8: 116-126

Arashkevich EG (1977) Duration of food digestion in marine copepods. Pol Arch Hydrobiol 24 (Suppl):431-438

Atkinson A, Snyder R (1997) Krill-copepod interactions at South Georgia, Antarctica, I. Omnivory by Euphausia superba. Mar Ecol Prog Ser 160:63-76

Båmstedt U, Karlson K (1998) Euphausiid predation on copepods in coastal waters of the Northeast Atlantic. Mar Ecol Prog Ser 172:149-168

Bergström B, Strömberg JO (1997) Behavioral differences in relation to pycnoclines during vertical migration of the euphausiids Meganyctiphanes norvegica (M. Sars) and Thysanoessa raschii (M. Sars). J Plankton Res 19:255-261

Bligh EG, Dyer W (1959) A rapid method of total lipid extraction and purification. Can J Biochem Physiol 37:911-917

Bollens SM, Stearns DE (1992) Predator-induced changes in the diel feeding cycle of a planktonic copepod. J Exp Mar Biol Ecol 156:179-186
Buchholz F, Buchholz C, Reppin J, Fischer J (1995) Diel vertical migrations of Meganyctiphanes norvegica in the Kattegat: comparison of net catches and measurements with Acoustic Doppler Current Profilers. Helgol Wiss Meeresunters 49:849-866

Donachie SP, Saborowski R, Peters G, Buchholz F (1995) Bacterial digestive enzyme activity in the stomach and hepatopancreas of Meganyctiphanes norvegica (M. Sars, 1857). J Exp Mar Biol Ecol 188:151-165

Einarsson H (1945) Euphausiacea. I. Northern Atlantic species. Dana-Rep Carlsberg Found 27:1-184

Falk-Petersen S, Sargent JR, Tande KS (1987) Lipid composition of zooplankton in relation to the sub-Arctic food web. Polar Biol 8:115-120

Fedorenko AY (1975) Instar and species specific diets in two species of Chaborus. Limnol Oceanogr 20:238-249

Fevolden SE (1982) Feeding habits and enzyme polymorphism in Thysanoessa raschii and Meganyctiphanes norvegica (Crustacea; Euphausiacea). Sarsia 67:1-10

Fisher LR, Goldie EH (1959) The food of Meganyctiphanes norvegica (M. Sars) with an assessment of the contributions of its components to the Vitamin A reserves of the animal. J Mar Biol Assoc UK 38:291-312

Gabriel W, Thomas B (1988) Vertical migration of zooplankton as an evolutionary stable strategy. Am Nat 132: 199-216

Geller W (1975) Die Nahrungsaufnahme von Daphnia pulex in Abhängigkeit von der Futterkonzentration, der Temperatur, der Körpergrösse und dem Hungerzustand der Tiere. Arch Hydrobiol Suppl 48:47-107

Gibbons MJ (1993) Vertical migration and feeding of Euphausia lucens at two $72 \mathrm{~h}$ stations in the southern Benguela Upwelling region. Mar Biol 116:257-268

Gibbons MJ, Pillar SC, Stuart V (1991) Selective carnivory by Euphausia lucens. Contin Shelf Res 11:625-640

Gibbons MJ, Spridinov VA, Tarling GA (1999) Euphausiacea. In: Boltovskoy D (ed) Zooplankton of the south-west Atlantic Ocean. Backhuys Publishers, Leiden, p 1241-1280

Hardy AC, Bainbridge R (1954) Experimental observations on the vertical migrations of planktonic animals. J Mar Biol Assoc UK 33:409-448

Itoh K (1970) A consideration of the feeding habits of planktonic copepods in relation to the structure of their oral parts. Bull Plankton Soc Japan 17:1-10

Karlson K, Båmstedt U (1994) Planktivorous predation on copepods. Evaluation of mandible remains in predator guts as a quantitative estimate of predation. Mar Ecol Prog Ser 108:79-89

Kattner G, Krause M (1989) Seasonal variations in lipid (wax esters, fatty acids and alcohols) in calanoid copepods from the North Sea. Mar Chem 26:261-275

Klages N (1979) Untersuchungen zur Nahrungsbiologie des nordischen Krills Meganyctiphanes norvegica. Dipl. thesis, University Kiel, Kiel

Klages N (1983) Der nordische Krill Meganyctiphanes norvegica (M. Sars). PhD thesis, University Kiel, Kiel

Krebs JR, McCleery RH (1984) Optimization in behavioural ecology. In: Krebs JR, Davies NB (eds) Behavioural ecology: an evolutionary approach, 2nd edn. Blackwell Scientific Publications, Oxford, p 99-121

MacDonald R (1927) Food and habits of Meganyctiphanes norvegica. J Mar Biol Assoc UK 14:753-784

Mangel M, Clark CW (1988) Dynamic modelling in behavioral ecology. Princeton University Press, Princeton, NJ

Marchant R, Hynes HBN (1981) Field estimates of feeding rate for Gammarus pseudolimnaeus (Crustacea: Amphipoda) in the Credit River, Ontario. Freshw Biol 11:27-36 
Matthews JBL, Buchholz F, Tarling GA, Saborowski R, Dallot S, Labat JP (1999) On the physical oceanography of the Kattegat and Clyde Sea area, as background to ecophysiological studies of the planktonic crustacean, Meganyctiphanes norvegica. Helgoland Mar Res 53:70-84

Matthews JBL, Mayzaud P, Tarling GA, Bedo A, Lass S, Buchholz F, Saborowski R (2000) The trophic environment of the euphausiid Meganyctiphanes norvegica in the Kattegat, the Clyde Sea area and the Ligurian Sea: chlorophyll concentrations and zooplankton biomass and species composition. Internal Report No. 227 Scottish Association for Marine Science, Oban, Argyll, UK

Mauchline J (1960) The biology of the euphausiid crustacean Meganyctiphanes norvegica Sars. Proc R Soc Edinb B(Biol) 67:141-179

Mauchline J, Fisher LR (1969) The biology of euphausiids. Adv Mar Biol 7:1-454

Mayzaud P, Virtue P, Albessard E (1999) Seasonal variations in lipid and fatty acid composition of the euphausiid Meganyctiphanes norvegica from the Ligurian Sea. Mar Ecol Prog Ser 189:199-210

McClatchie S (1985) Feeding behavior in Meganyctiphanes norvegica (M. Sars) (Crustacea:Euphausiacea). J Exp Mar Biol Ecol 86:271-284

Morris DJ, Ricketts C (1984) Feeding of krill around South Georgia. I. A model of feeding activity in relation to depth and time of day. Mar Ecol Prog Ser 16:1-7

Murtaugh PA (1981) Selective predation by Neomysis mercedis in Lake Washington. Limnol Oceanogr 26:445-453

Murtaugh PA (1984) Variable gut residence time: problems in inferring feeding rate from stomach fullness of a mysid crustacean. Can J Fish Aquat Sci 41:1287-1293

Nichols PD (1990) Occurrence of novel C30 sterols in Antarctic sea-ice diatom community during a spring bloom. Org Geochem 15:503-508

Nichols PD, Palmisano A, Rayner MS, Smith GA, White DC (1989) Changes in the lipid composition of Antarctic seaice diatom community physiological status. Antarct Sci 1: $133-140$

Nicol S (1984) Population structure of daytime surface swarms of the euphausiid Meganyctiphanes norvegica in the Bay of Fundy. Mar Ecol Prog Ser 18:241-251

Ohman MD (1984) Omnivory by Euphausia pacifica: the role of copepod prey. Mar Ecol Prog Ser 19:125-131

Omori M, Ikeda T (1984) Methods in marine zooplankton ecology. John Wiley \& Sons, New York

Onsrud MSR, Kaartvedt S (1998) Diel vertical migration of the krill Meganyctiphanes norvegica in relation to physical

Editorial responsibility: Otto Kinne (Editor),

Oldendorf/Luhe, Germany environment, food and predators. Mar Ecol Prog Ser 171: 209-219

Ponomareva LA (1971) Circadian migrations and feeding rhythm of some Indian Ocean euphausiid species. Oceanology 11:226-231

Saborowski R, Buchholz F (1999) A laboratory study on digestive processes in the Antarctic krill, Euphausia superba, with special regard to chitinolytic enzymes. Polar Biol 21: 295-304

Sameoto DD (1980) Relationships between stomach contents and vertical migration in Meganyctiphanes norvegica, Thysanoessa raschii and T. inermis (Crustacea:Euphausiacea). J Plankton Res 2:129-143

Sars GO (1903) An account of the Crustacea of Norway. VI. Copepoda Calanoida. Bergen museum, Bergen

Schnack S (1982) The structure of the mouth parts of copepods in Kiel Bay. Meeresforschung 29:89-101

Simmard Y, Ladurantaye Rd, Therriault JC (1986) Aggregation of euphausiids along a coastal shelf in an upwelling environment. Mar Ecol Prog Ser 32:203-215

Stuart V, Huggett JA (1992) Prey selection by Euphausia lucens (Hansen) and feeding behavior in response to a mixed algal and animal diet. J Exp Mar Biol Ecol 164:117-133

Tarling GA, Matthews JBL, Sabarowski R, Buchholz F (1998) Vertical migratory behaviour of the euphausiid Meganyctiphanes norvegica, and its dispersion in the Kattegat Channel. Hydrobiologia 375/376:331-341

Tarling GA, Buchholz F, Matthews JBL (1999) The effect of a lunar eclipse on the vertical migration of Meganyctiphanes norvegica (Crustacea: Euphausiacea) in the Ligurian Sea. J Plankton Res 21:1475-1488

Tarling GA, Matthews JBL, Burrows M, Saborowski R, Buchholz F, Bedo A, Mayzuad P (2000) An optimisation model of the diel vertical migration of 'Northern krill' (Meganyctiphanes norvegica) in the Clyde Sea and Kattegat. Can J Fish Aquat Sci 57(Suppl 3):38-50

Virtue P, Nicol S, Nichols PD (1993) Changes in the digestive gland of Euphausia superba during short-term starvation: lipid class, fatty acid and sterol content and composition. Mar Biol 117:441-448

Virtue P, Nichols PD, Nicol S, Hosie G (1996) Reproductive trade-off in male Antarctic krill. Mar Biol 126:521-527

Volkman JK (1986) A review of sterol markers for marine and terrigenous organic matter. Org Geochem 9:83-99

Wiebe PH, Morton AW, Bradley AM, Backus RH, Craddock JE, Barber V, Cowles TJ, Flierl GR (1985) New developments in the MOCNESS, an apparatus for sampling zooplankton and micronekton. Mar Biol 87:313-323

Submitted: April 25, 2000; Accepted: September 6, 2000

Proofs received from author(s): April 2, 2001 